\title{
Modification of the Quaternary stratigraphic framework of the inner-continental shelf by Holocene marine transgression: An example offshore of Fire Island, New York
}

\author{
William C. Schwab a,*, Wayne E. Baldwin ${ }^{a}$, Jane F. Denny ${ }^{a}$, Cheryl J. Hapke ${ }^{b}$, Paul T. Gayes ${ }^{c}$, \\ Jeffrey H. List ${ }^{\mathrm{a}}$, John C. Warner ${ }^{\mathrm{a}}$ \\ a U.S. Geological Survey, Woods Hole Coastal and Marine Science Center, 384 Woods Hole Road, Woods Hole, MA 02543-1598, USA \\ ${ }^{\mathrm{b}}$ U.S. Geological Survey, St. Petersburg Coastal and Marine Science Center, 600 Fourth Street South, St. Petersburg, FL 33701, USA \\ c Center for Marine and Wetland Studies, Coastal Carolina University, 1270 Atlantic Avenue, Conway, SC 29526, USA
}

\section{A R T I C L E I N F O}

\section{Article history:}

Received 16 December 2013

Received in revised form 23 June 2014

Accepted 25 June 2014

Available online 3 July 2014

\section{Keywords:}

seafloor mapping

inner-continental shelf

shoreface

sand ridges

sorted bedforms

sediment transport

ravinement surface

Quaternary stratigraphy

\begin{abstract}
A B S T R A C T
The inner-continental shelf off Fire Island, New York was mapped in 2011 using interferometric sonar and highresolution chirp seismic-reflection systems. The area mapped is approximately $50 \mathrm{~km}$ long by $8 \mathrm{~km}$ wide, extending from Moriches Inlet to Fire Island Inlet in water depths ranging from 8 to $32 \mathrm{~m}$. The morphology of this inner-continental shelf region and modern sediment distribution patterns are determined by erosion of Pleistocene glaciofluvial sediments during the ongoing Holocene marine transgression; much of the shelf is thus an actively forming ravinement surface. Remnants of a Pleistocene outwash lobe define a submerged headland offshore of central Fire Island. East of the submerged headland, relatively older Pleistocene outwash is exposed over much of the inner-continental shelf and covered by asymmetric, sorted bedforms interpreted to indicate erosion and westward transport of reworked sediment. Erosion of the eastern flank of the submerged Pleistocene headland over the last $\sim 8000$ years yielded an abundance of modern sand that was transported westward and reworked into a field of shoreface-attached ridges offshore of western Fire Island. West of the submerged headland, erosion of Pleistocene outwash continues in troughs between the sand ridges, resulting in modification of the lower shoreface. Comparison of the modern sand ridge morphology with the morphology of the underlying ravinement surface suggests that the sand ridges have moved a minimum of $\sim 1000 \mathrm{~m}$ westward since formation. Comparison of modern sediment thickness mapped in 1996-1997 and 2011 allows speculation that the nearshore/shoreface sedimentary deposit has gained sediment at the expense of deflation of the sand ridges.
\end{abstract}

Published by Elsevier B.V.

\section{Introduction}

The evolution of coastal areas, from individual storm events to millennial time scales, is linked directly to the oceanographic processes acting on the geologic framework of the adjacent inner-continental shelf (Swift, 1976; Riggs et al., 1995; Thieler et al., 1995, 2001; Wright, 1995; Schwab et al., 2000a, 2013; Cowell et al., 2003; Miselis and McNinch, 2006; Fagherazzi and Overeem, 2007; Denny et al., 2013; Twichell et al., 2013). Fire Island, a segment of a barrier island system extending along the south coast of Long Island, New York (Fig. 1), is the focus of an ongoing study led by the U.S. Geological Survey (USGS) designed to observe oceanographic processes controlling circulation and sediment transport in the coastal ocean. These observations are

\footnotetext{
* Corresponding author. Tel.: + 1508457 2299; fax: +1 5084572309.

E-mail address: bschwab@usgs.gov (W.C. Schwab).
}

critical for advancing development of physics-based numerical models required to provide accurate predictions of coastal change and a thorough understanding of sediment response to oceanographic and geologic processes in the shoreface/inner-continental shelf environment (e.g., Warner et al., 2012).

Fire Island attracts significant tourism, includes federal, state, and county parks, contains a number of coastal communities, provides storm damage protection to the adjacent heavily populated mainland, and supports a distinct barrier island ecosystem, all of which are affected by coastal erosion. Mitigating the impacts of coastal erosion has been an important management objective for decades. Thus, coastal erosion and sediment budget analyses in the Fire Island barrier-island system have been conducted and debated in the scientific and engineering literature (e.g., Gofseyeff, 1952; Saville, 1960; Panuzio, 1968; Kumar and Saunders, 1974; Williams, 1976; Leatherman and Allen, 1985; Kana, 1995; Morang et al., 1999; Smith et al., 1999; Schwab et al., 2000a, 2013; Hapke et al., 2010). It is well documented that a primary 

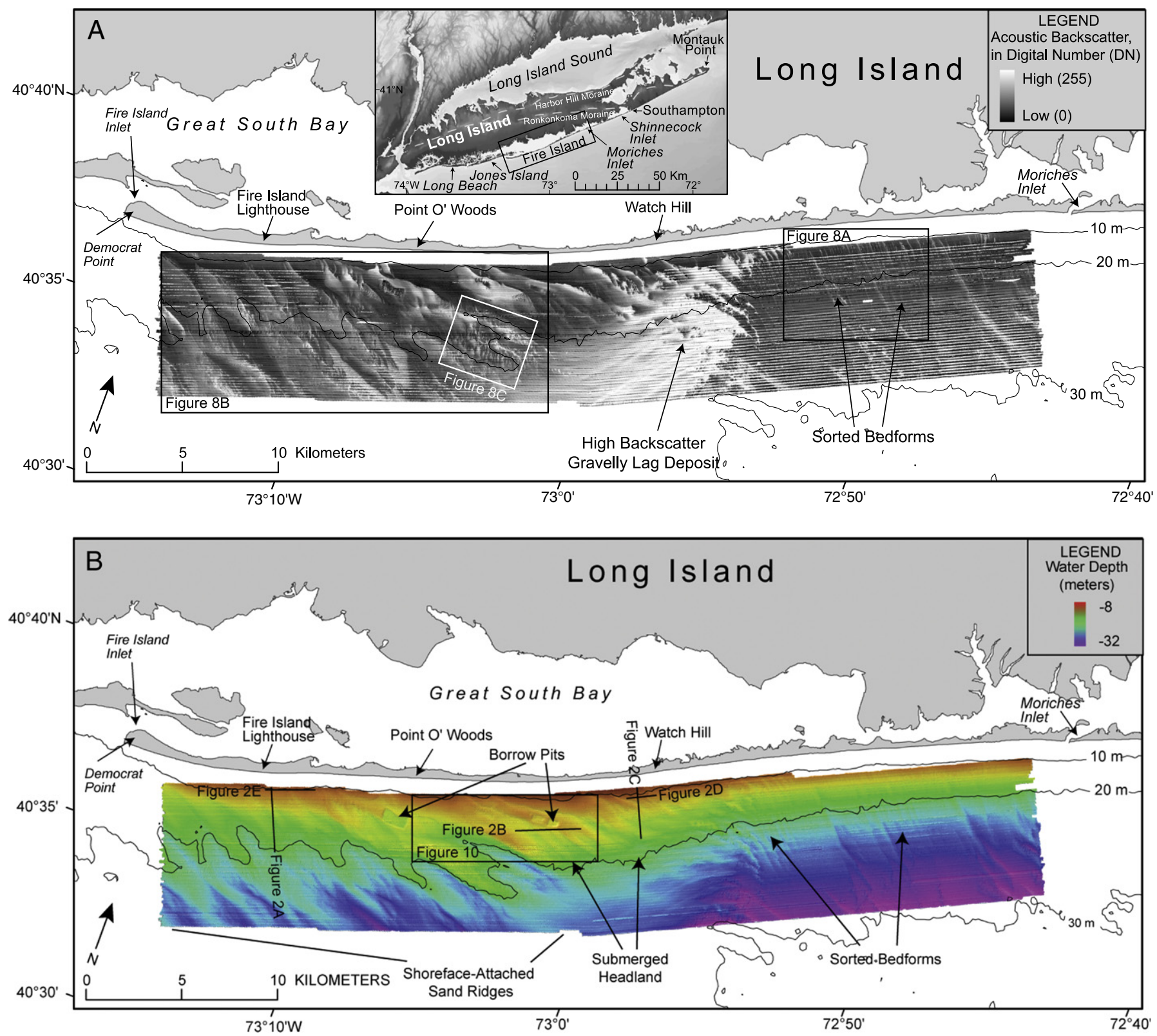

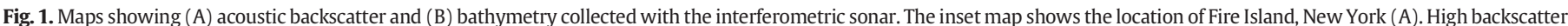

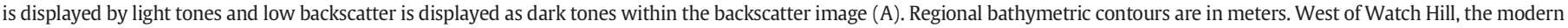

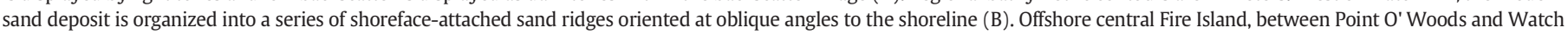

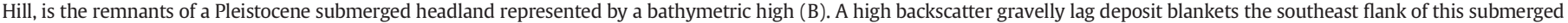
headland (A). East of Watch Hill, the seafloor is covered by sorted bedforms.

Figure modified from Schwab et al. (2013).

component of sediment transport in this system is directed alongshore from east to west, but discrepancies in volumetric sediment budget calculations remain (see Hapke et al., 2010 and references therein). An additional quantity of sand, averaging $\sim 200,000 \mathrm{~m}^{3} / \mathrm{yr}$ is required to explain the growth of the western segment of the barrier island (Hapke et al., 2010), which is a prograding spit (Leatherman and Allen, 1985).

In 2011, a high-resolution marine geophysical survey of the lower shoreface and inner-continental shelf was conducted offshore of Fire Island. The survey area extends $\sim 50 \mathrm{~km}$ alongshore and extends $\sim 8 \mathrm{~km}$ offshore in water depths ranging from $\sim 8$ to $32 \mathrm{~m}$ (Fig. 1B). The density of this 2011 marine geophysical data provides an ideal opportunity to visualize how erosion and formation of a ravinement surface associated with Holocene marine transgression shaped and continues to modify inner-continental shelf morphology and sediment distribution. These same processes affect many coastal areas undergoing marine transgression. Thus, a conceptual model of shelf-shoreface evolution developed using observations south of Fire Island has broad applications to other sandy coastal areas and has implications for modeling coastal behavior, mitigating coastal erosion and coastal zone management.

A ravinement surface is a diachronous surface eroded by waves and currents during marine transgression, the morphology of which is controlled by the antecedent topography of the transgressive unconformity, erosion resistance, sediment supply, and the rate of transgression (Kraft et al., 1987; Nummedal and Swift, 1987). The common interpretation of the complex interaction between the shoreface and ravinement surface is that, as the shoreline retreats, all sediment above the depth of ravinement is reworked while sediments below are preserved (e.g., Belknap and Kraft, 1981; 1985; Demarest and Kraft, 1987). The toe of 
the shoreface is the narrow relatively steeply sloping zone between the seaward limit of the shore at low water and the nearly horizontal inner-continental shelf. It is widely assumed to approximate the depth of storm wave base (limit of wave-induced sediment transport) and has been used as a minimum estimate for the depth of shoreface ravinement (e.g., Swift, 1968; Nummedal and Swift, 1987). However, erosion, transport and deposition of sediment in deeper-water, innercontinental shelf settings have been well documented (e.g., Pilkey and Field, 1972; Sternberg and Larsen, 1975; Gadd et al., 1978; Lavelle et al., 1978; Cacchione and Drake, 1982; Cacchione et al., 1984, 1987; Vincent et al., 1982; Wiberg and Smith, 1983; Wright et al., 1986, 1991, 1994). Thus, in this paper, the geomorphic expression of the Fire Island shoreface is not meant to imply the width of a nearshore zone of active sediment transport nor the seaward limit of processes forming a ravinement surface.

Schwab et al. (2013) used high-resolution seafloor mapping techniques and historical shoreline analyses to investigate how the geologic framework of the inner-continental shelf influenced the Holocene evolution and modern behavior of Fire Island. Their findings suggested that a realistic coastal sediment budget must include sediment input from the inner-continental shelf. In this paper, maps of the geometry and structure of the Quaternary sedimentary deposits offshore of Fire Island are presented. These maps and geophysical data are used to form a conceptual model of the Holocene evolution of the inner-continental shelf and shoreface, a consequence of marine transgression of Pleistocene glaciofluvial sedimentary deposits.

\section{Regional geologic setting}

Long Island, New York marks the southern terminus of the Wisconsinan Laurentide glacial advance in the eastern part of North America (Stone and Borns, 1986). The coast from Southampton to Montauk Point is a headland region where the Ronkonkoma moraine (Fig. 1A) and associated outwash sediment are eroded directly by wave action (Williams, 1976). The south shore of Long Island west of Southampton consists of reworked outwash and includes shallow back-barrier bays, marshes, and low-relief, sandy barrier islands (Leatherman and Allen, 1985). Located within this barrier-island system is Fire Island, a 0.5 - to $1.0-\mathrm{km}$-wide, $50-\mathrm{km}$-long island that is bound by two tidal inlets, Moriches Inlet to the east and Fire Island Inlet to the west (Fig. 1).

The Quaternary stratigraphy of the coastal zone of southern Long Island and the adjacent continental shelf was shaped by Pleistocene glaciation and the associated glacial isostatic depression, forebudge collapse, and re-emergence (Dillon and Oldale, 1978) as well as eustatic sea-level fluctuations (Lisiecki and Raymo, 2005). Repeated emergence and submergence of the continental shelf led to regional truncation and localized dissection of the Cretaceous- to early Tertiary-age coastal plain strata and the overlying Quaternary section by erosion during transgressions and subaerial fluvial incision during regressions.

Williams (1976) provided an interpretation of major innercontinental shelf sedimentary sequences offshore of New York using a regional seismic-reflection survey conducted in 1968 and correlation with cores, land borings, and exposures. He indicated that Upper Cretaceous-age coastal plain strata on the inner-continental shelf south of Long Island are unconformably overlain by Pleistocene sediment, with no preservation of Tertiary-age sedimentary units. This regional hiatus, first identified by Emery and Uchupi $(1965,1972)$ and referred to as the coastal plain unconformity, is believed to have formed initially during the mid-Oligocene and is correlative with the Atlantic coastal-plain reflector of Poag (1978) and Hutchinson and Grow (1984). The coastal plain unconformity also has been identified beneath the adjacent subaerial area of Long Island as a contact between Upper Cretaceous-age strata and overlying Pleistocene sediment (Suter et al., 1949; Williams, 1976; Soren, 1978; Smolensky et al., 1989). Planar internal reflectors on seismic-reflection profiles identify the coastal plain strata, which thicken to the southeast along the entire length of Long Island (Williams, 1976). Approximately $10 \mathrm{~km}$ south of Long Beach (Fig. 1), the Pleistocene sediment cover is thin and coastal plain strata and associated gravelly lag deposits crop out on the seafloor (Williams and Duane, 1974; Williams, 1976; Williams and Meisburger, 1987; Schwab et al., 1997). The coastal plain strata are thought to contain semi-lithified, interbedded marine deposits of clay, silt, and sand of the Cretaceous-age Monmouth Group (Williams, 1976; Smolensky et al., 1989).

Where the coastal plain strata are buried by Quaternary sediment, the regional unconformity between them can be observed in seismicreflection profiles throughout the New York Bight and on the innercontinental shelf south of Long Island (Williams, 1976; Schwab et al., 1997; Foster et al., 1999). Pleistocene sediments overlying this unconformity are interpreted to be glaciofluvial outwash deposits composed of gravel to fine sand that were deposited during the Middle and Late Wisconsinan (Marine Isotope Stages 2 and 4) glacial maximum (Williams, 1976; Schwab et al., 1997; Foster et al., 1999). These Pleistocene sediment deposits are either exposed over much of the inner-continental shelf south of Long Island or, in places, covered by modern, reworked sand deposits (Williams, 1976; Foster et al., 1999; Schwab et al., 2000a).

The modern sand deposit on the inner-continental shelf south of Long Island is derived from erosion of the Cretaceous coastal plain strata and Pleistocene glaciofluvial deposits exposed on the inner-continental shelf by oceanographic processes during the Holocene marine transgression; its distribution is discontinuous and variably thick (Williams, 1976; Foster et al., 1999; Schwab et al., 2000a,b). Previous interpretation of marine geologic mapping data supports the hypothesis that the Holocene evolution of Fire Island, including its modern decadal to centennial timescale behavior, is linked directly to the geologic framework of the inner-continental shelf (Schwab et al., 2000a, 2013; Lentz et al., 2013).

\section{Methods}

The inner-continental shelf south of Fire Island was mapped in 2011 using interferometric sonar and high-resolution seismic-reflection techniques. The geophysical survey covered $\sim 336 \mathrm{~km}^{2}$ extending $\sim 46 \mathrm{~km}$ along the coast from approximately the 8 - $\mathrm{m}$ isobath to $\sim 8 \mathrm{~km}$ offshore in water depths up to $\sim 32 \mathrm{~m}$ (Fig. 1). Data were acquired along $\sim 2800 \mathrm{~km}$ of trackline spaced $\sim 75-100 \mathrm{~m}$ apart in the shore-parallel direction with shore-perpendicular tie lines spaced $\sim 2 \mathrm{~km}$ apart. Navigation was recorded using a Differential Global Positioning System (DGPS).

Colocated acoustic backscatter (Fig. 1A) and swath bathymetry (Fig. 1B) were acquired using an interferometric sonar operating at a frequency of $234 \mathrm{kHz}$. Vessel heave, pitch, roll, and yaw (attitude) were recorded continuously and sound velocity profiles were collected approximately every $2 \mathrm{~h}$. Soundings were recorded over swath widths ranging from 50 to $150 \mathrm{~m}$, resulting in coverage of $~ 90 \%$ of the seafloor in the survey area. Vessel attitude and sound velocity data were used to reduce vessel motion and refraction artifacts and filters were used to remove redundant and spurious soundings. Real-time kinematic GPS height corrections, broadcast from a Continuously Operated Reference Station (CORS) at Central Islip, NY (station NYCI) were used to reference soundings to the North American Vertical Datum of 1988 and remove water depth variations caused by tides. Processed soundings were used to create an interpolated bathymetric grid with a resolution of $10 \mathrm{~m} /$ pixel (Fig. 1B). Acoustic backscatter data were radiometrically corrected using an empirical gain normalization function and mosaicked at a resolution of $10 \mathrm{~m} /$ pixel (Fig. 1A).

Chirp seismic-reflection data were collected using a chirp subbottom profiler (FM swept frequency of 0.5 to $12.0 \mathrm{kHz}$ ). Data were acquired using a 0.25 -s shot rate, a 5 -ms pulse length, and a $0.5-8.0-\mathrm{kHz}$ frequency sweep, recorded over two-way travel time trace lengths of $200 \mathrm{~ms}$ and 
logged in the SEG-Y Rev. 1 format. SIOSEIS (Henkart, 2011) seismic processing software was used to shift traces vertically to remove the effects of sea surface heave, mute water column portions of the traces, and apply time-varying gain and automatic gain control. Processed seismicreflection data were loaded into the seismic interpretation software package Landmark SeisWorks 2D where erosional unconformities (coastal plain, base of shallow Pleistocene outwash lobe, and Holocene transgressive unconformities) were identified and digitized. The twoway travel times between the seafloor and the unconformities were calculated and converted to thicknesses in meters using a constant velocity of $1500 \mathrm{~m} / \mathrm{s}$ to produce isopachs of the seismostratigraphic units. These interpretive maps were exported into ArcGIS and gridded with $50-\mathrm{m}$ cell sizes to produce DEMs of the isopachs and bounding unconformities relative to NAVD 88 (with the exception of the coastal plain unconformity which was gridded using a 100-m cell size); anything less than $50 \mathrm{~cm}$ in thickness is assumed to be 0 for sediment volume calculations due to a conservative estimate of limits in the vertical resolution of the seismicreflection data.

\section{Mapping results}

The inner-continental shelf south of Fire Island was mapped in 1996-1997 using sidescan-sonar and seismic-reflection techniques (Foster et al., 1999; Schwab et al., 2000a). The stratigraphic and sedimentologic frameworks derived from interpretation of the 2011 mapping data presented here map the same horizons, however the increased resolution of the 2011 data and collection of regional swath bathymetry allows a refinement and, in part, correction of the coastal plain and Pleistocene horizons presented by Foster et al. (1999) and Schwab et al. (2000a). In this section, detailed maps of the coastal plain unconformity and Holocene marine transgressive, or ravinement surface are presented. These maps and high-resolution bathymetry
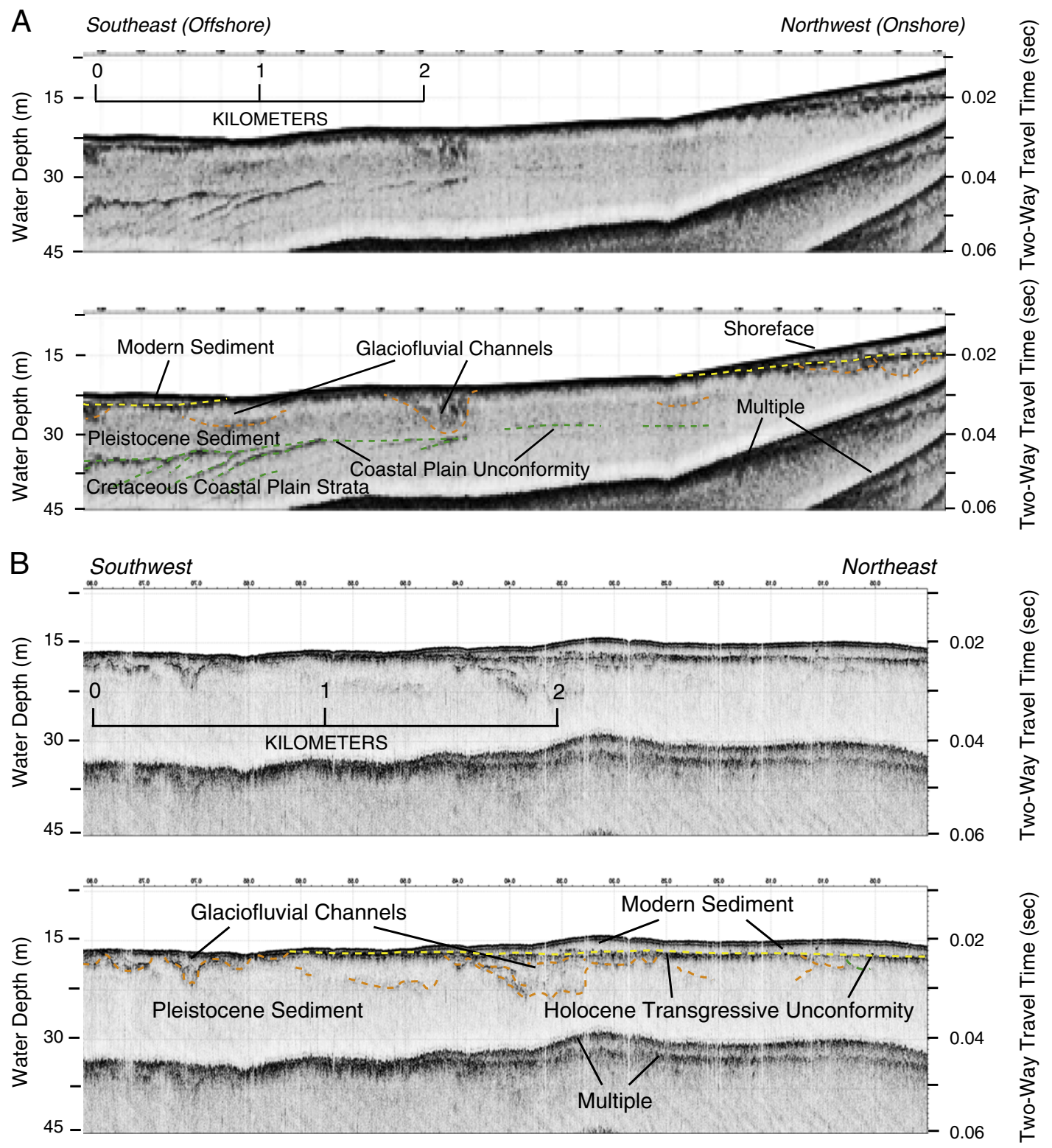

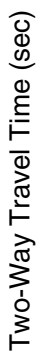

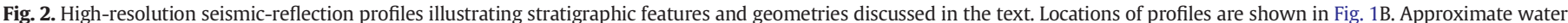

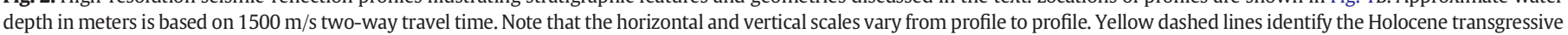

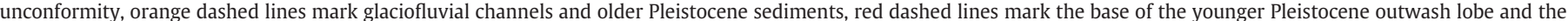

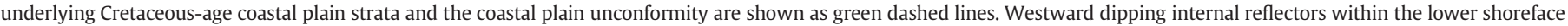
modern sediment deposit are shown as blue dashed lines.

Figure modified from Schwab et al. (2013). 

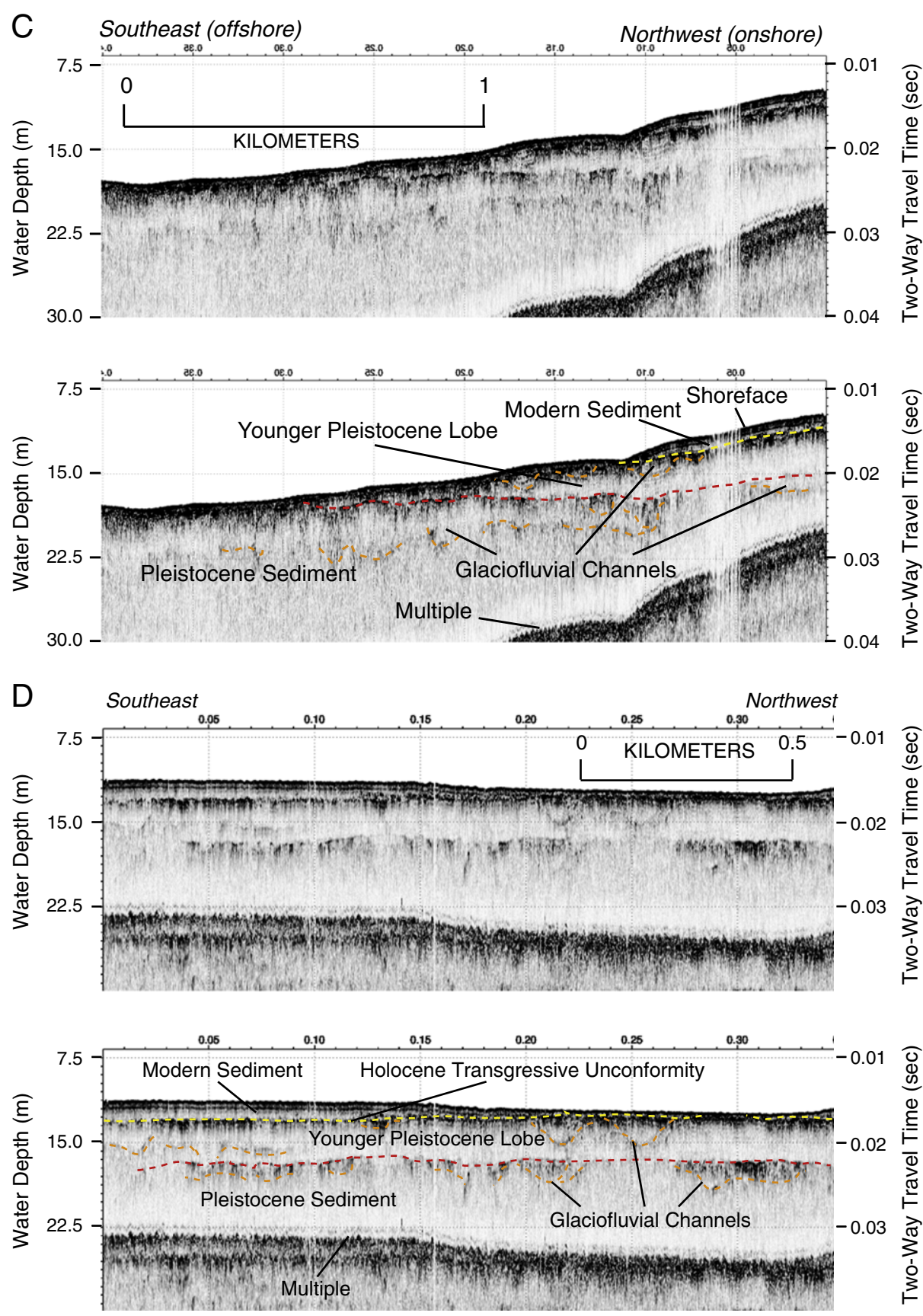

Fig. 2 (continued).

and acoustic backscatter data (Fig. 1) are used to produce maps of Quaternary and Holocene sediment thicknesses and to describe seafloor sediment distribution patterns.

\subsection{Coastal plain unconformity}

Coastal plain strata are recognizable on the inner-continental shelf south of Long Island as a series of high-amplitude, conformable reflectors that have a slightly variable, low-angle $\left(\sim 1^{\circ}\right)$, southeast dip and are truncated by the coastal plain unconformity (Fig. 2A), a regional angular unconformity (Williams, 1976). High-resolution seismicreflection data collected in 2011 and reprocessed data collected in 1996-1997 show that the coastal plain unconformity is a low-relief surface that dips from $\sim 25 \mathrm{~m}$ below sea level in the northwest corner of the study area to $\sim 40 \mathrm{~m}$ below sea level in the southeast corner (Fig. 3).

\subsection{Pleistocene glaciofluvial sediment}

The Pleistocene deposits immediately above the coastal plain unconformity are acoustically amorphous in places, and in other areas display discontinuous internal reflectors indicative of numerous cut-and-fill channel structures on seismic-reflection profiles (Fig. 2). These sediments are glaciofluvial outwash deposits composed of gravels to fine sand (Williams, 1976; Schwab et al., 1997, 2000a; Foster et al., 1999). The Pleistocene sediments comprise the bulk of the sedimentary section above the coastal plain unconformity and are either exposed at the seafloor over much of the study area east of Watch Hill and in the troughs between modern sand ridges west of Watch Hill or covered by a veneer $(<50 \mathrm{~cm})$ of reworked modern sediment that is below the $50-\mathrm{cm}$ resolution of our mapping systems (Fig. 4). Sediment grab samples (Schwab et al., 2000b) and cores (United States Army Corps 

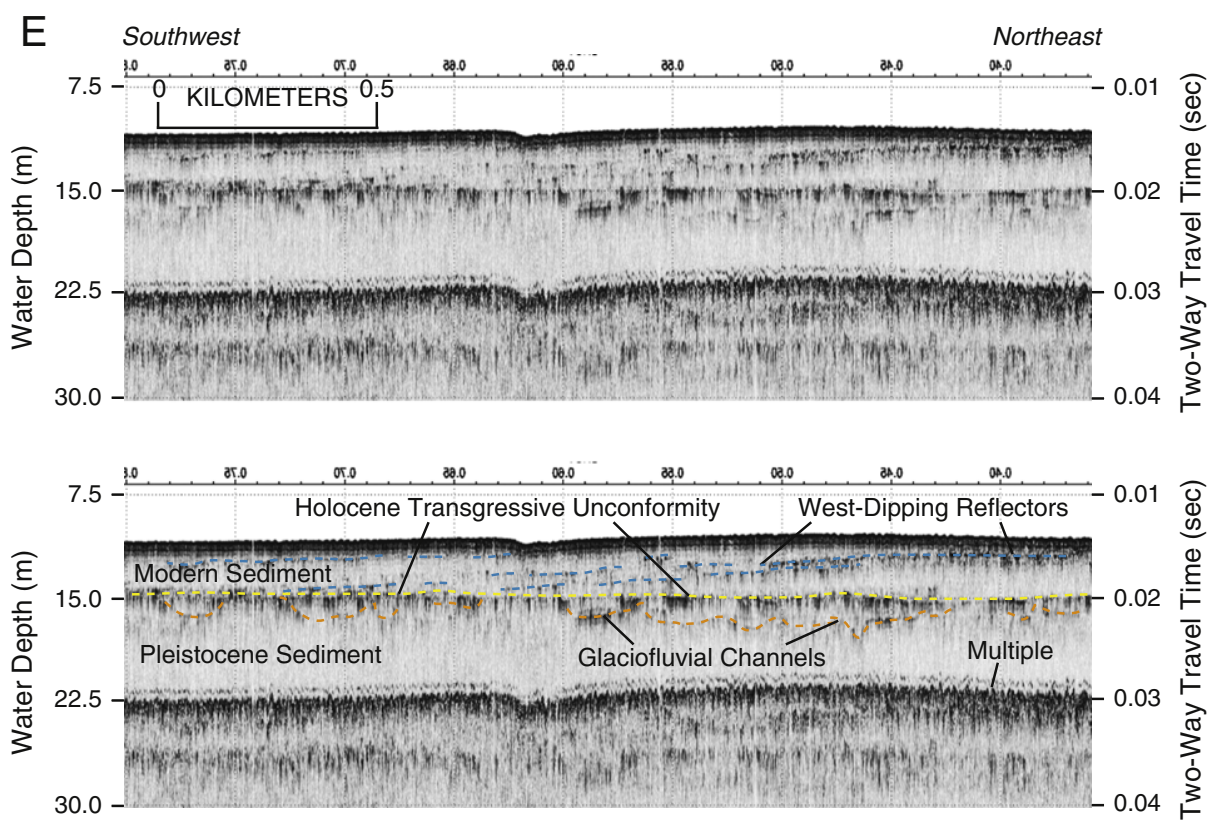

Fig. 2 (continued)

of Engineers (USACE), unpublished data) show that the outcropping Pleistocene sediments consist of poorly to very poorly sorted mediumgrained sand to gravel; with a mean grain size coarser than $1.0 \phi$ and a standard deviation $>1.0 \phi$. Seaward of the eastern segment of Fire Island, interferometric sonar data collected over outcropping Pleistocene sediments show numerous high backscatter, $<2 \mathrm{~m}$ deep, linear depressions oriented $\sim 60^{\circ}-70^{\circ}$ to the shoreline (Fig. 1 ).

In the central part of the study area, the remnants of a distinct, younger glaciofluvial outwash lobe can be identified in the 2011 mapping data (Figs. 2C, D). The base of this deposit is a hummocky, irregular unconformity separating it from underlying, older Pleistocene deposits. These younger deposits are acoustically similar to the older deposits, including discontinuous cut-and-fill channel structures, and can be identified on seismic-reflection profiles in water depths less than $\sim 18 \mathrm{~m}$. This young outwash lobe is, in places, up to $\sim 6 \mathrm{~m}$ thick (Fig. 5 ) and may correlate with the Late Pleistocene "upper outwash deposit" identified in well borings on Fire Island, a fine- to coarse grained sand with some gravel (Schubert, 2009).

The Quaternary deposits thicken to $\sim 18 \mathrm{~m}$ offshore of the central segment of Fire Island (Fig. 6). This increased thickness is, in part, correlative with the location of remnants of the younger Pleistocene outwash lobe (Fig. 5) and its expression in the modern bathymetry (Fig. 1B) forms a submerged headland. Seaward of the remnants of the young outwash lobe, on the southeast flank of the headland in water depths of $\sim 18-28 \mathrm{~m}$, a gravelly lag deposit is reworked forming a series of northeast-southwest trending, high-backscatter, $50-\mathrm{cm}-$ high, linear bedforms (Fig. 5) (Schwab et al., 2013).

\subsection{Holocene sediment}

The acoustically transparent, Holocene sedimentary deposit on the inner-continental shelf offshore of Fire Island consists of relict and modern components. Unpublished vibracore data (USACE) and sediment grab samples (Schwab et al., 2000b) show that some of the paleochannels incising the upper surface of the Pleistocene deposit are filled with a transgressive sequence of glaciofluvial sediment capped by early Holocene muddy estuarine sediment (Schwab et al., 2000a). Modern sediment lies unconformably atop the Pleistocene glaciofluvial and early Holocene channel-fill deposits (Fig. 2). Foster et al. (1999) identified this horizon as the Holocene transgressive unconformity or ravinement surface (Fig. 7). The modern sediment ranges from very fine to medium-grained, moderately to well-sorted sand; mean grain size ranges from 1.0 to $3.5 \phi$ with a standard deviation $<1 \phi$ (Schwab et al., 2000b).

In the area west of Watch Hill, the modern sedimentary deposit forms a series of northwest-southeast-trending, shoreface-attached sand ridges (Fig. 1B) which are oriented at angle of $\sim 20^{\circ}$ to $40^{\circ}$ to the shoreline offshore of central Fire Island and increasing to $\sim 50^{\circ}$ at the western limit of the study area (Duane et al., 1972; Schwab et al., 2000a). These sand ridges extend seaward across the study area and are up to $\sim 5 \mathrm{~m}$ thick offshore of central Fire Island, thinning westward to $<1 \mathrm{~m}$ thick offshore of the western limit of the study area (Fig. 4).

\subsection{Shoreface}

Modern sediment also forms the shoreface and subaerial beach system. The seaward extent, or toe of the modern shoreface (Fig. 4) is identified on seismic-reflection profiles lying unconformably above the Pleistocene glaciofluvial and early Holocene channel-fill deposits (Figs. 2A, C). In the study area west of Watch Hill, it is difficult to define the toe of the shoreface based solely on seismic-reflection profiles because the sediment forming the lower shoreface and sand ridges attached to it is acoustically indistinguishable, with the exception of a series of high-amplitude, west-dipping internal reflectors in profiles acquired over the shoreface deposit west of Point O' Woods (Fig. 2E), which are discussed below. Mapping the break in slope from the bathymetry (Fig. 1B) and sediment thickness from seismic-reflection profiles indicates that the toe of the shoreface extends to a water depth of $\sim 16$ m west of Point O' Woods and although highly variable, shoals to an average of $\sim 13$ m east of Point O' Woods (Fig. 4).

\section{Discussion}

Transgressive sedimentary deposits are of interest to the scientific and engineering communities. The formation of a time-transgressive subaqueous erosional surface resulting from nearshore marine and shoreline erosion associated with sea level rise and the formation of transgressive sedimentary deposits is fundamental to the development of sequence stratigraphic concepts for continental shelf evolution (e.g., Posamentier, 2002). Coastal sediment budgets and associated coastal 


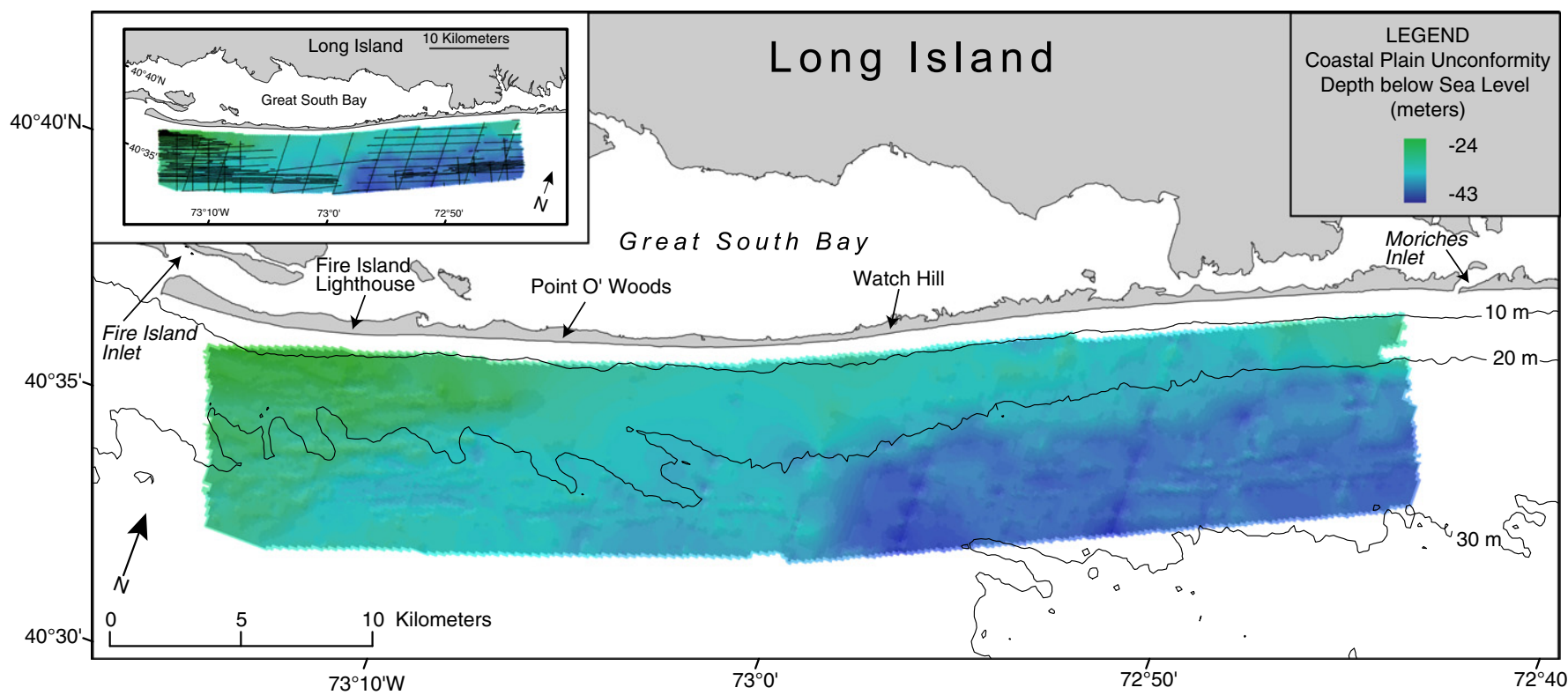

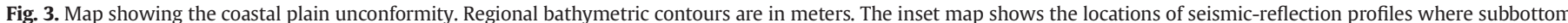

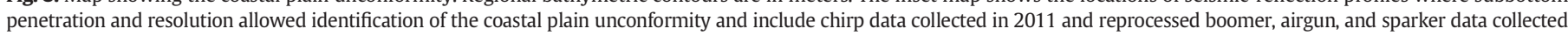

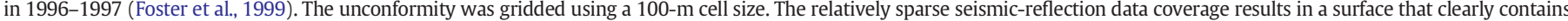
trackline artifacts and a relatively higher uncertainty in comparison with other maps presented.
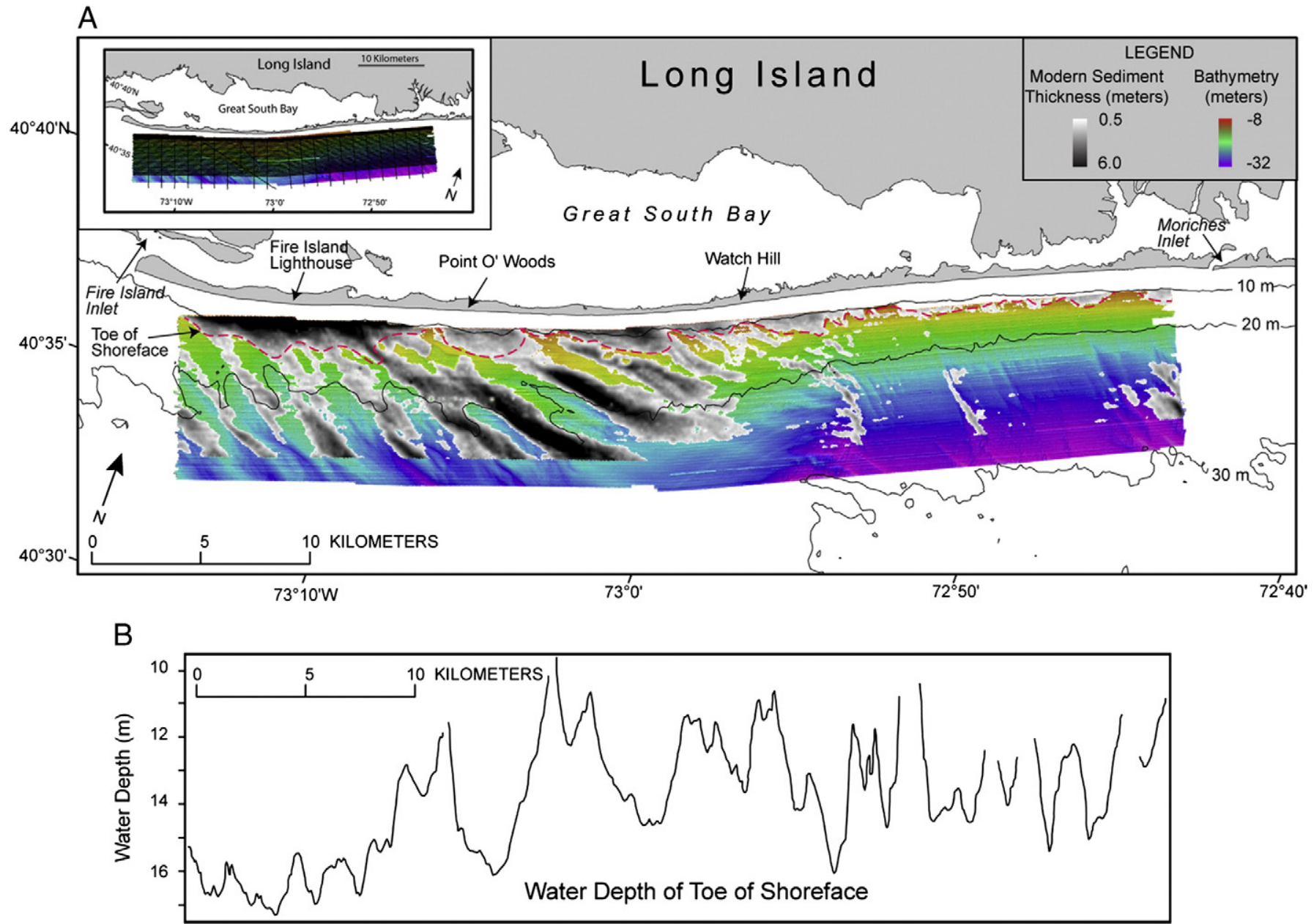

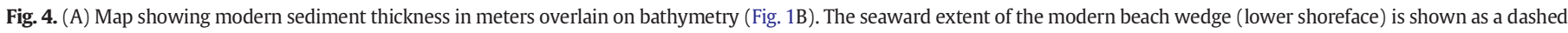

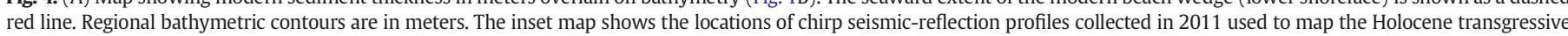
unconformity and thus the modern sediment thickness. (B) Profile showing water depth of toe of the lower shoreface shown in (A). 
change can be significantly influenced by the antecedent geology being eroded and the availability of nearshore transgressive sand deposits (Riggs et al., 1995; Thieler et al., 1995; Schwab et al., 2000a, 2013; Gayes et al., 2003; Miselis and McNinch, 2006; Hapke et al., 2011; Denny et al., 2013; Twichell et al., 2013). The analysis of the lower shoreface and inner-continental shelf bathymetry, sediment distribution, bedform patterns, and seismostratigraphy presented here supports previous hypotheses (Schwab et al., 2013 and references therein) that: (A) erosion of the Pleistocene glaciofluvial and early Holocene channelfill sediment deposits offshore of Fire Island during Holocene marine transgression formed the present morphology of the inner-continental shelf and sediment distribution patterns; and (B) processes associated with ongoing marine transgression and formation of a ravinement surface yield a relatively finer grained modern sand deposit that is transported in a net westerly direction.

\subsection{Erosion of the inner-continental shelf offshore of eastern Fire Island}

The Holocene transgressive unconformity on most of the innercontinental shelf east of the Pleistocene outwash headland (Fig. 7) is exposed at the seafloor or buried under $\mathrm{a}<50$-cm-thick veneer of modern sediment (Fig. 4). Numerous high-backscatter, $<2$-m-deep, linear depressions oriented $\sim 60^{\circ}$ to $70^{\circ}$ to the adjacent shoreline (Fig. 1 ) are interpreted to be sorted bedforms (also known as rippled scour depressions). Murray and Thieler (2004) suggest that the presence of sorted bedforms is indicative of active erosion of the seafloor, where a feedback mechanism develops when near-bed turbulence causes the scour of fine sand in the presence of a continuous current, which in turn prevents any new accumulation of fine sand in the scoured region. In other innercontinental shelf settings where sorted bedforms have been mapped in high resolution, they tend to be asymmetric with their relatively coarser flanks facing up current, opposite to the direction of dominant sediment transport (Murray and Thieler, 2004; Goff et al., 2005 and references therein). Thus, Schwab et al. (2013) interpreted the relatively higher-backscatter base and eastward-facing flanks of the sorted bedform troughs offshore of eastern Fire Island (Fig. 8A) to be indicative of continued erosion of the seabed by oceanographic processes and net westward transport direction of reworked sediment.

\subsection{Erosion of the Pleistocene headland offshore of central Fire Island}

The Holocene transgressive surface (Fig. 7) clearly depicts a submerged headland, consisting of the eroded southeastern margin of a relatively young Pleistocene outwash lobe offshore of the central portion of Fire Island (Fig. 5). Remnants of the outwash lobe headland crop out on the seafloor offshore of central Fire Island in water depths $\leq 18 \mathrm{~m}$ (Fig. 2C). Geophysical and sediment core evidence (Williams, 1976; Swift and Moslow, 1982; Leatherman and Allen, 1985; Schwab et al., 2000a) and Holocene sea-level indicators for the U.S. Atlantic coast (Engelhart et al., 2011) show that this headland was subaerially exposed and for the past $\sim 8000 \mathrm{yr}$ the shoreline has migrated landward in response to marine transgression from a location near the present $18-\mathrm{m}$ isobath. The high-backscatter gravelly lag deposit identified on the southeast flank of the headland in water depths from $\sim 18$ to $28 \mathrm{~m}$ (Fig. 1) is interpreted to originate from erosion of the young outwash lobe during this marine transgression and although speculative, it may represent the southeastern extent of the original lobe prior to transgression (Schwab et al., 2013). The organization of this gravelly lag deposit into low-amplitude, linear bedforms (Fig. 5) offers additional evidence that erosion and modification of the seabed may continue during severe storms, although it is unknown if these are modern or relict features.

It is impossible to determine the volume of sediment eroded from the submerged headland offshore of central Fire Island during marine transgression. However, if the assumption that the location of the gravelly lag deposit indicates the pre-transgression seaward extent of the young outwash lobe is correct, we speculate that erosion associated with marine transgression yielded an abundant volume of very fineto medium-grained sand.

\subsection{Erosion of the inner-continental shelf offshore of western Fire Island}

West of Watch Hill, the ravinement surface is blanketed by a field of shoreface-attached sand ridges $\sim 1-6 \mathrm{~m}$ thick and oriented $\sim 20^{\circ}$ to $50^{\circ}$ to the shoreline which dominate the morphology of the innercontinental shelf (Figs. 1B and 8B). Similar ridges have been described in numerous investigations of the North American inner-continental shelf where they have amplitudes from $\sim 1$ to $10 \mathrm{~m}$, become more

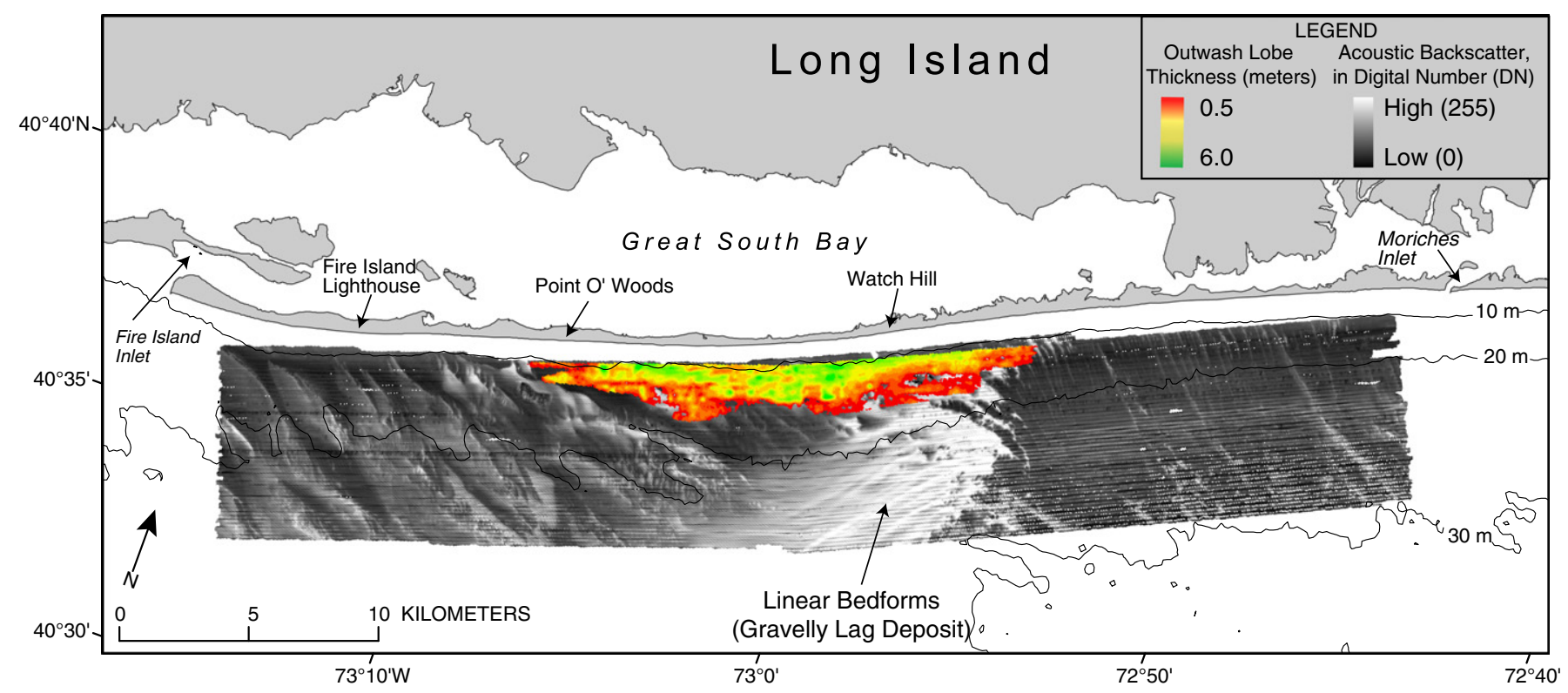

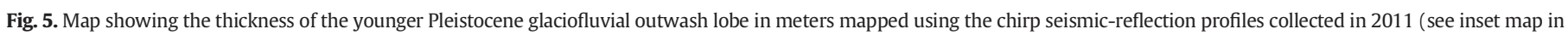
Fig. 4), overlain on acoustic backscatter (Fig. 1A). Regional bathymetric contours are in meters. 


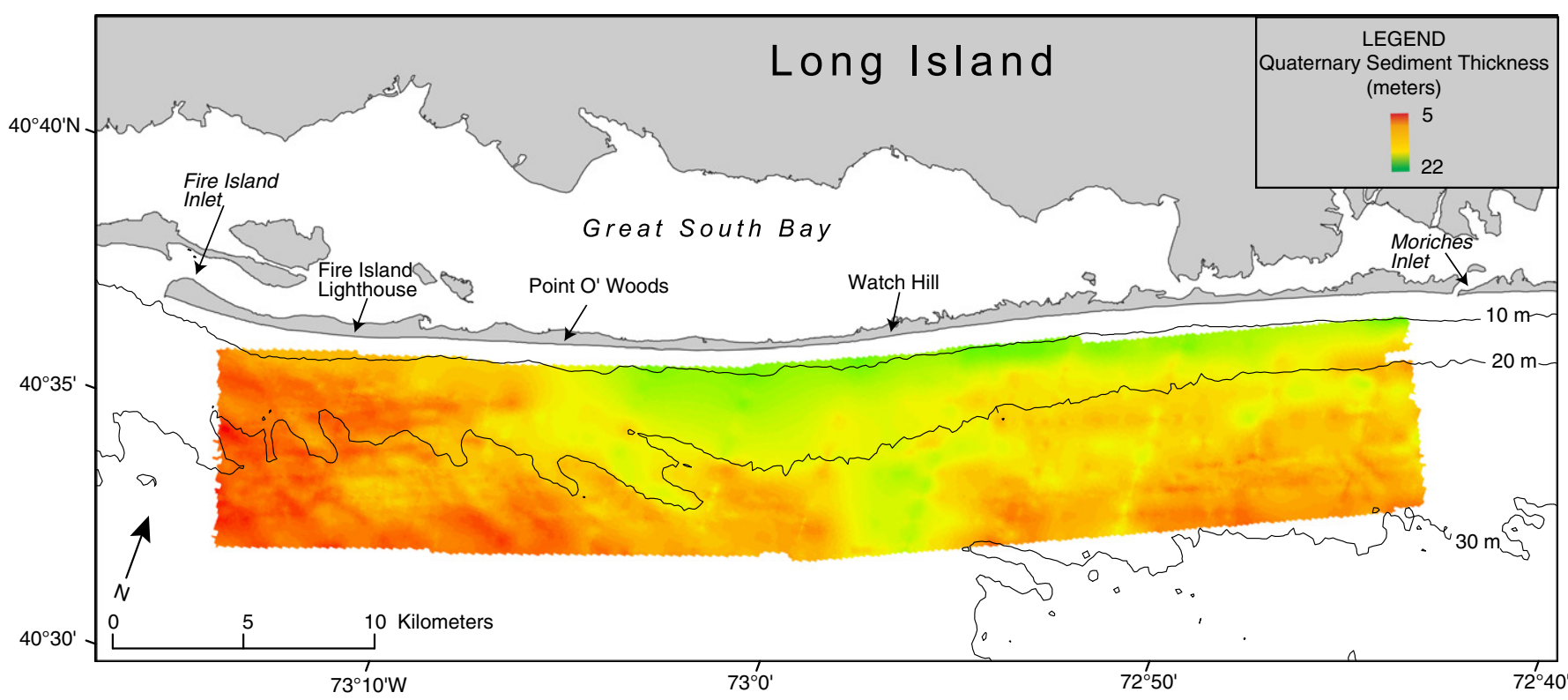

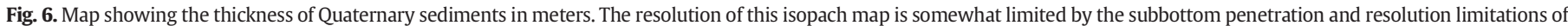
the seismic-reflection profiles used to identify the coastal plain unconformity (see inset map in Fig. 3). Regional bathymetric contours are in meters.

asymmetric with increasing water depth, and their longitudinal axes are typically oriented $\sim 10^{\circ}-50^{\circ}$ relative to the shoreline, matching the predominant storm wave approach direction and open into the flow direction of the dominant alongshore current (Duane et al., 1972; McKinney et al., 1974; Swift and Freeland, 1978; Figueiredo et al., 1981; Swift and Field, 1981; Stubblefield et al., 1984). The similarity in characteristics suggests that a common process (or processes) is responsible for the origin and maintenance of these features.

A number of processes have been proposed to form and maintain shoreface-attached sand ridges; see reviews in Goff et al. (1999, 2005), Snedden et al. (1999), Van de Meene and Van Rihn (2000), Hayes and Nairn (2004), and Son et al. (2012a,b). Most have concluded that sand ridges originate on the shorefaces of barrier islands and ridge formation and maintenance require a sufficient source of sand, currents to move the sand, and bathymetric irregularities resulting from transgressive sediment dispersal that act as nuclei for the ridge formation (e.g., Swift et al., 1978; Huthnance, 1982; Nummedal and Swift, 1987). Swift and Field (1981) proposed that ridge formation begins on the upper shoreface in response to alongshore storm currents. As the ridges grow in amplitude, they undergo alongshore, down-current migration, while at the same time the eroding shoreface retreats out from under them. A widely cited theory of origin and maintenance of shorefaceattached sand ridges is that of Trowbridge (1995), modified by Calvette et al. (2001) and Vis-Star et al. (2007), who used stability analysis to show that sand ridges can be created, maintained, and enhanced during storm-driven alongshore-directed flow.

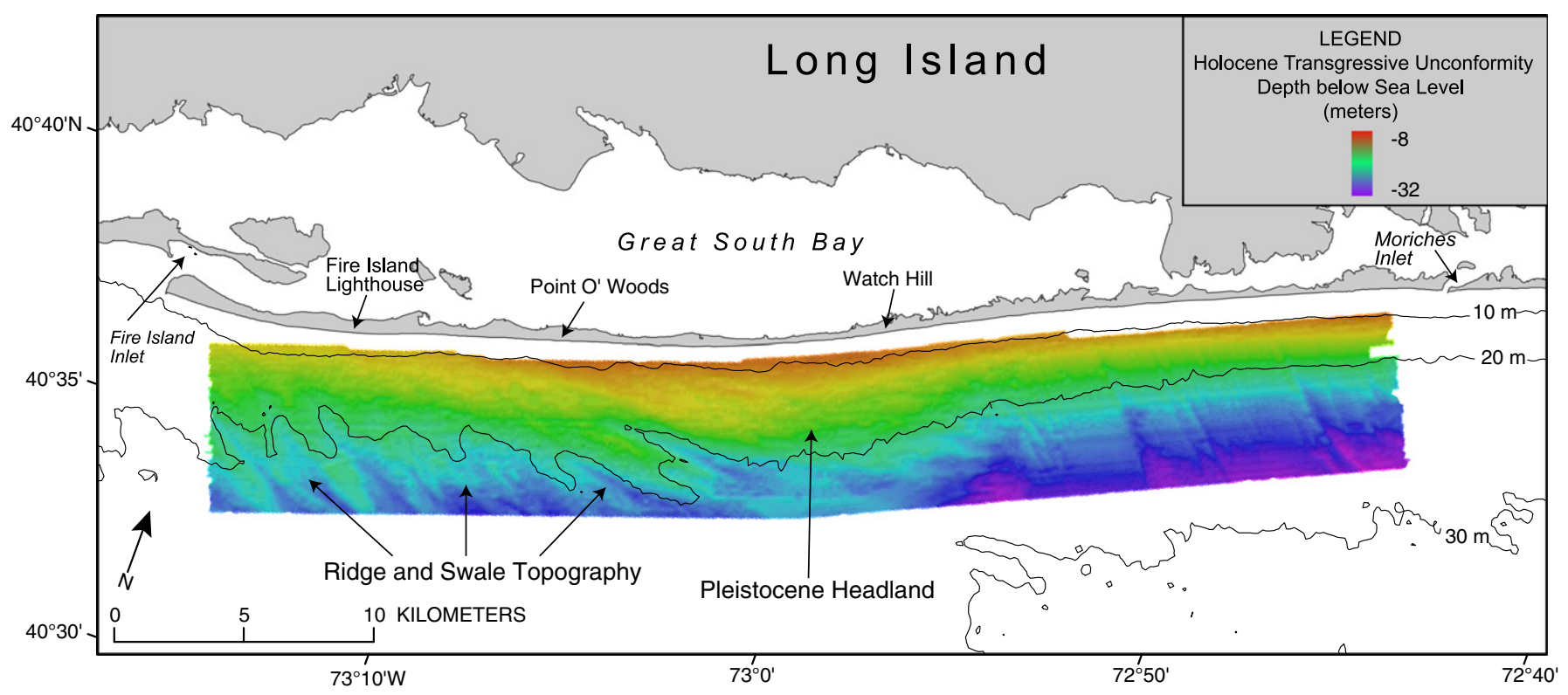

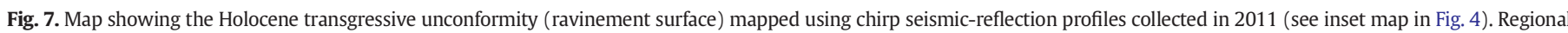
bathymetric contours are in meters. 
Schwab et al. (2013) inferred that the erosion of the Pleistocene headland offshore of central Fire Island during Holocene marine transgression yielded an abundance of very fine- to medium-grained, well-sorted, modern sand, which has been transported to the west, providing a primary source of sediment for development of the shoreface-attached sand ridges west of Watch Hill. Progressive thinning of these sand ridges westward, with increasing distance from the proposed source area (Fig. 4) further supports this hypothesis.

Similar to the inner-continental shelf offshore of central and eastern Fire Island, the seafloor west of Point O' Woods is also dynamic and being actively modified. Sand waves with wavelengths $\geq 100 \mathrm{~m}$ and amplitudes $\leq 0.5 \mathrm{~m}$ cover portions of both the modern sand ridges and the Pleistocene glaciofluvial and early Holocene channel-fill deposits exposed in the troughs between them (Fig. 8C). Comparison of backscatter data collected in 1996-1997 to backscatter data collected in 2011 verifies that these sand waves moved westward up to $75 \mathrm{~m}$ (Schwab et al., 2013). Erosion of outcropping Pleistocene glaciofluvial and early Holocene channel-fill sedimentary deposits in troughs between the sand ridges has modified and continues to modify the Holocene marine transgressive surface, forming a ridge-and-swale topography on this unconformity (Fig. 7). We assume that modern sand derived from the continued erosion of the Holocene transgressive surface represents an additional source of modern sediment for maintenance of the sand ridges.

A
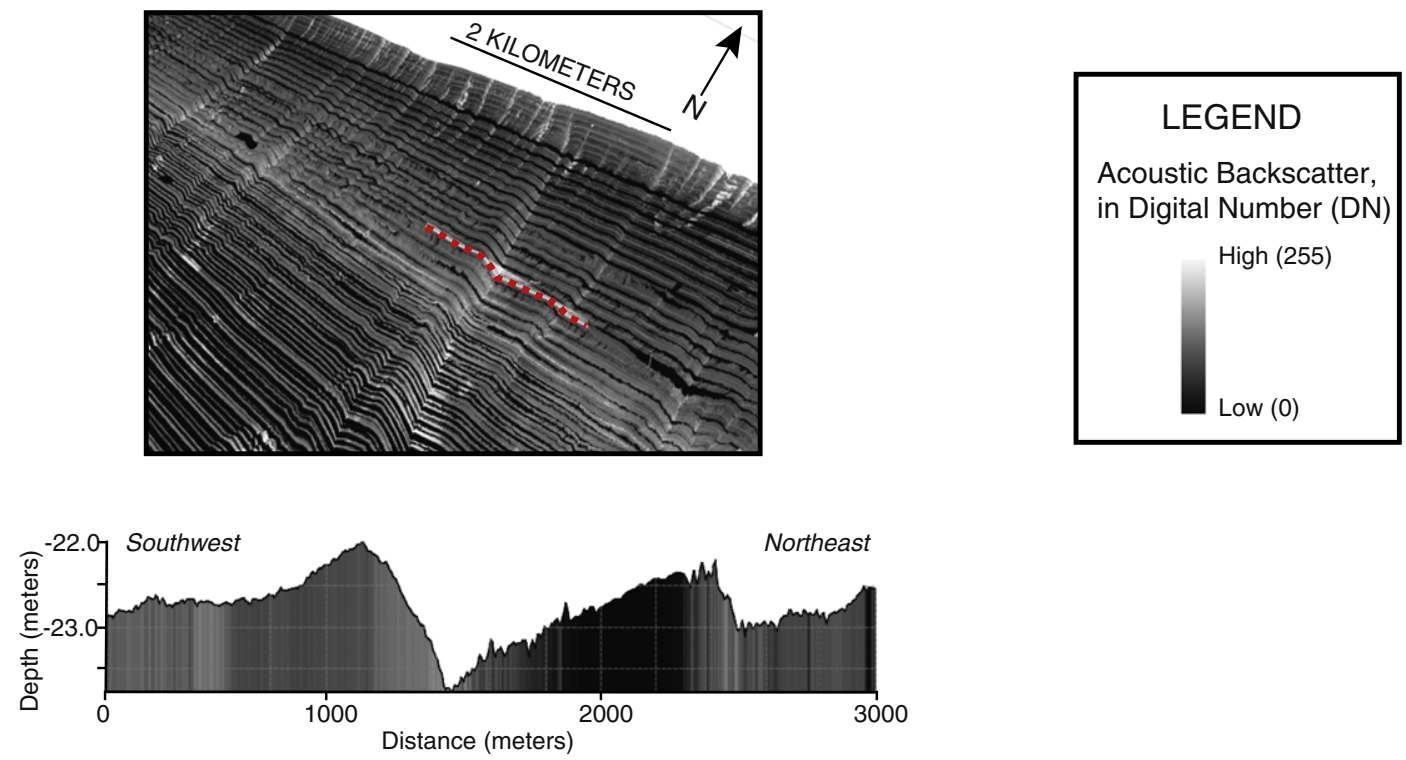

B
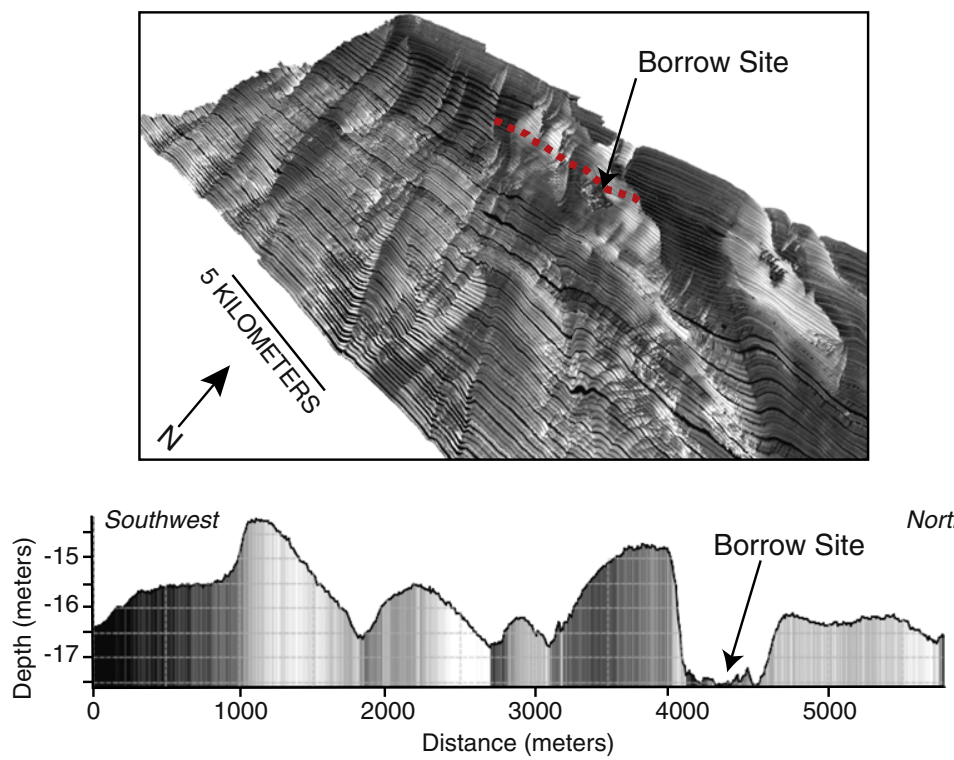

C

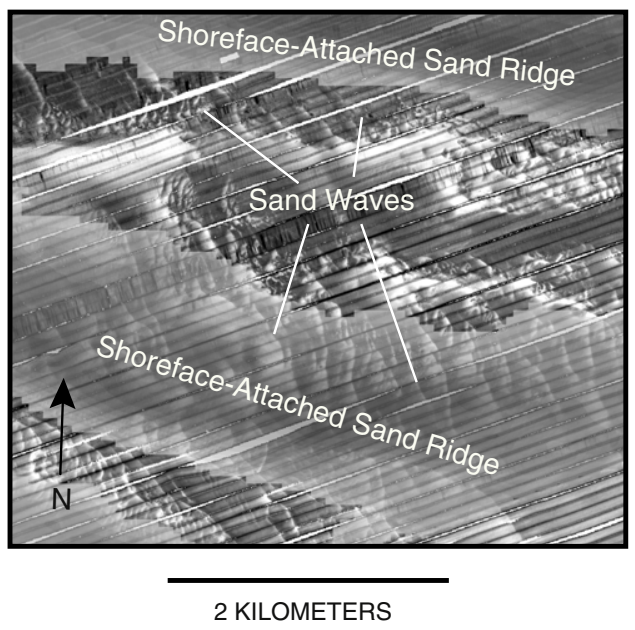

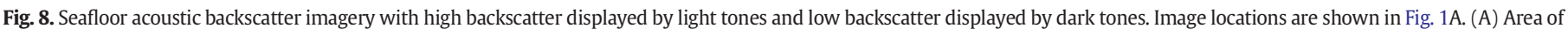

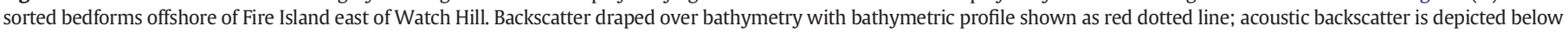

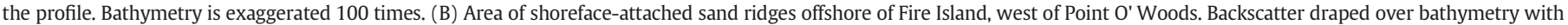

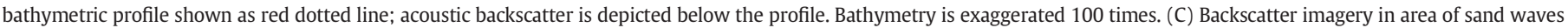
on shoreface attached sand ridges and in troughs between ridges. Holocene sediment thickness (Fig. 4A) is overlain to show the location of sand ridges.

Figure modified from Schwab et al. (2013). 
The eastward-facing flanks of the shoreface-attached sand ridges display higher backscatter than the westward-facing flanks (Fig. 8B). This backscatter pattern is indicative of net westward sediment transport, with currents transporting fine-grained sand across the sand wave crest, leaving slightly coarser grained, higher backscatter on the eastward-facing flanks of the sand ridges (Schwab et al., 2013). Superimposing the present location of the sand ridges over the Holocene transgressive unconformity shows that the topography of the seaward extent of the ridges is, in places, up to $~ 1000 \mathrm{~m}$ out of phase with the ridge and swale topography of the underlying transgressive unconformity (Fig. 9). Goff and Duncan (2012) made similar observations in their study of sand ridges on the continental shelf offshore of New Jersey. This indicates that the sand ridges offshore of western Fire Island have moved in a westward direction since formation. This interpretation identifies the modern sedimentary deposit as the more mobile sediment in this nearshore environment, in contrast with the coarser-grained, more consolidated Pleistocene glaciofluvial and early Holocene channel-fill deposits from which the modern sediment is derived. The rate of ridge movement is difficult to assess considering that it is unknown when these sand ridges formed. In addition, the swales in the exposed Holocene transgressive surface would also be expected to migrate as the ravinement surface is exposed at the seafloor and subjected to erosion, albeit at a lower rate than the sand ridge migration; the mobile modern sediment (sand ridges) is migrating over a lessmobile substrate. Nonetheless, interpretation of southwest migration of these ridges is consistent with models of shoreface-connected ridge migration rates of 1 to $10 \mathrm{~m} / \mathrm{yr}$ in energy environments similar to southern Long Island (Trowbridge, 1995; Calvette et al., 2001; and Vis-Star et al., 2007) and similar to rates of sand ridge movement recognized offshore of the Outer Banks, NC (Thieler et al., 2013).

The southwest-facing flanks of the larger sand ridges offshore of Fire Island terminate in $\sim 1$-m-high scarps in water depths $\leq 17 \mathrm{~m}$ (Fig. 10). In places where the sand ridges attach to the lower shoreface, these scarps define the toe of the shoreface (Fig. 4). Comparison of acoustic backscatter collected in 1996-1997 with data collected in 2011 shows that in places these scarps have migrated up to $150 \mathrm{~m}$ landward (Schwab et al., 2013). Whether the onshore migration of the scarps on the seaward-facing flanks of the sand ridges indicates long-term depletion of the sand ridges (or in places, the toe of the shoreface) or ephemeral oscillations in the morphology of the sand ridge cannot be determined by the comparison of only two temporal datasets. However, we speculate that this scarp morphology is oscillatory and the result of

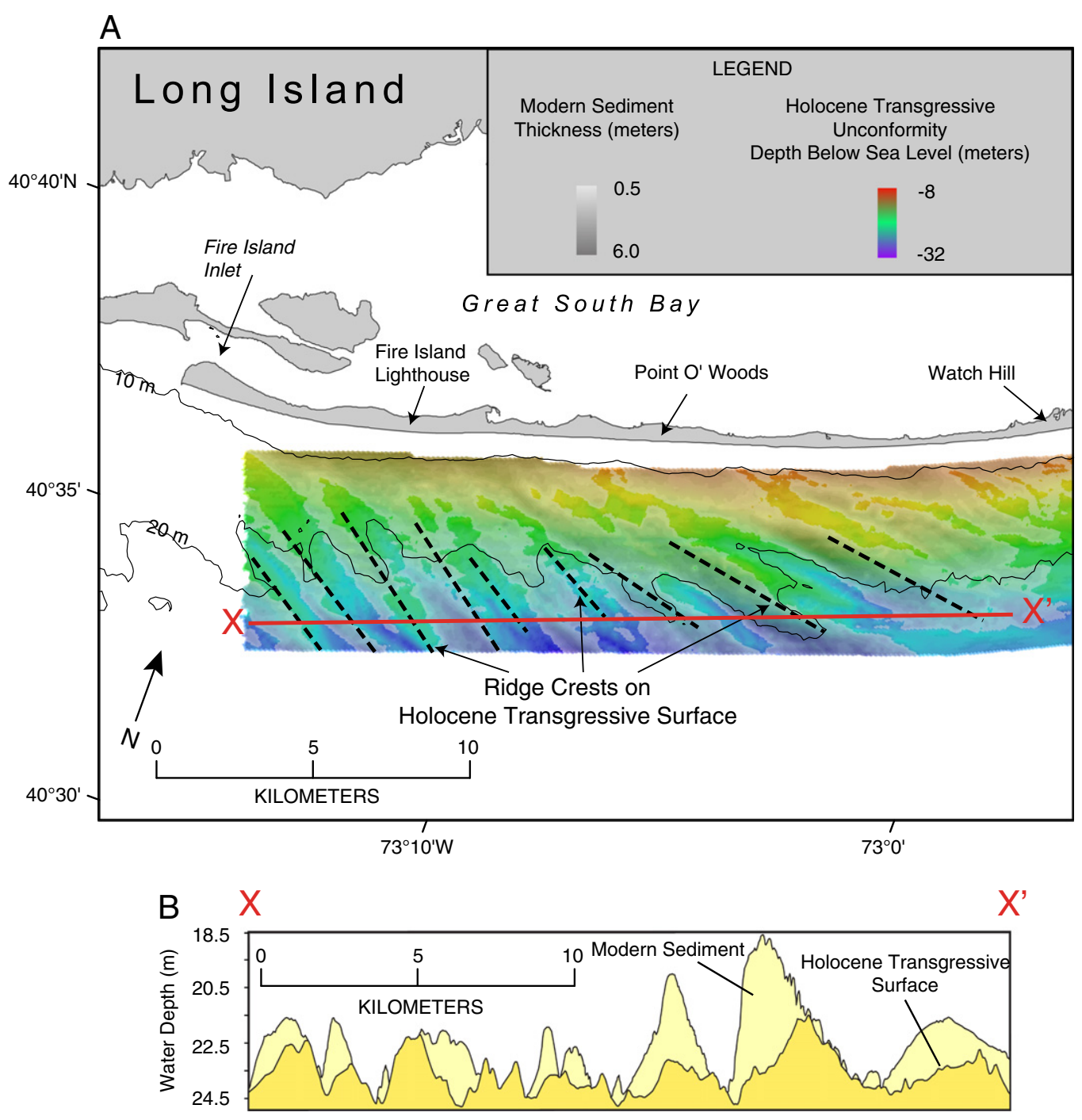

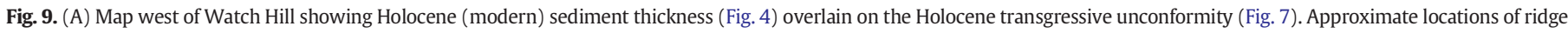

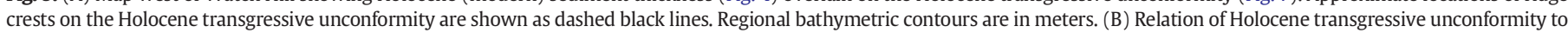
bathymetry (Fig. 1B) along profile $\mathrm{X}-\mathrm{X}^{\prime}$ shown in (A). 


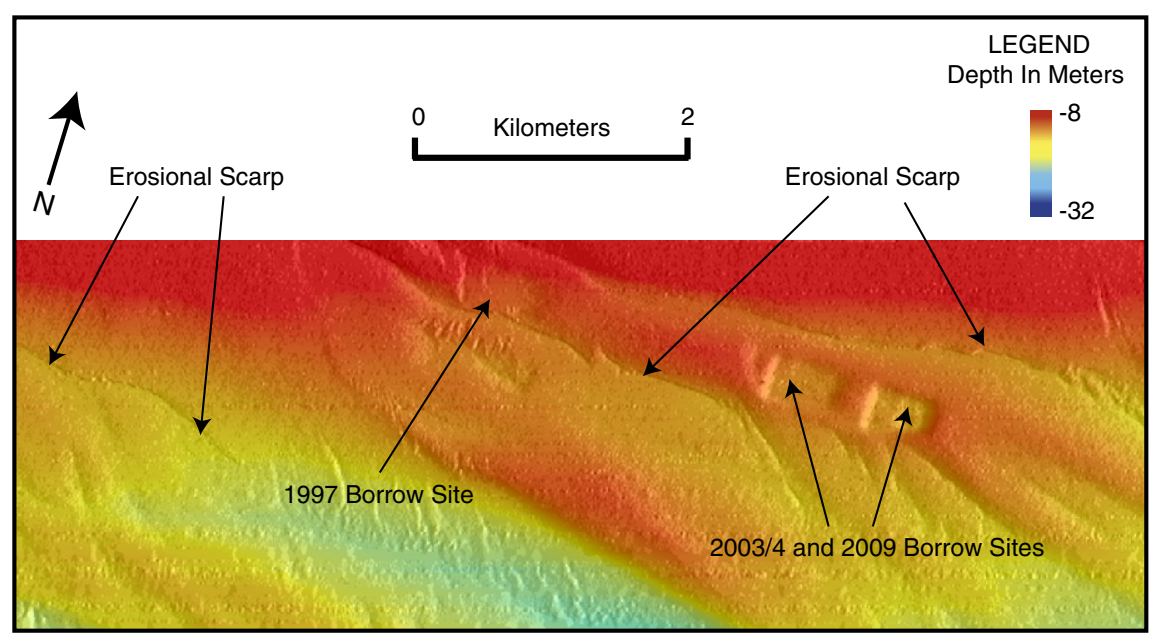

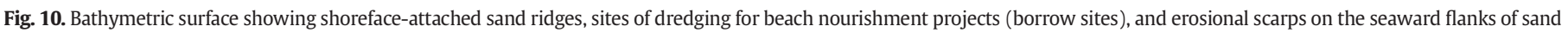
ridges. Location is shown in Fig. 1B.

the ongoing modification of the ravinement surface, where erosion in the troughs between the sand ridges modifies the flanks of the sand waves and the toe of the shoreface.

An additional complexity in interpreting the geologic mapping of this dynamic system is that the inner-continental shelf modern sand deposit has been heavily mined since 1994 for beach replenishment activities (Kana, 1995; Gravens et al., 1999; Rosati et al., 1999; Lentz et al., 2013). How the processes that control the morphology of the sand ridges and development of the ravinement surface are impacted by these mining activities is unknown. These sand ridges remain a primary target for mining in support of future planned beach nourishment projects. Quantification of how changes in sand ridge morphology influence wave conditions and currents and the subsequent changes to the shoreface morphology will be a component of the future USGS sediment transport processes research in the Fire Island study area.

\subsection{Evolution of the lower shoreface}

The lower shoreface deposits of the eastern, central, and western segments of Fire Island show differences that can be associated with the amount of modern sediment available on the inner-continental shelf (Fig. 4). Although variable, the thickness of shoreface sediment along the $10-\mathrm{m}$ isobath is on average $<2 \mathrm{~m}$ thick east of Watch Hill, $\sim 2-3 \mathrm{~m}$ thick between Watch Hill and Point O' Woods, and up to $\sim 5 \mathrm{~m}$ west of Point $\mathrm{O}^{\prime}$ Woods. This geometry is, in part, due to the relatively steeper gradient of the Holocene transgressive unconformity (Fig. 7), and thus the inner-continental shelf offshore of the island segment east of Watch Hill relative to that west of Point O' Woods, and because the shoreface offshore of the island segment between Point O' Woods and Watch Hill is perched on top of the submerged Pleistocene headland (Figs. 2C and 7).

This lower shoreface sedimentary deposit is acoustically transparent on seismic-reflection profiles in the central segment and extremely thin in the eastern segment, but displays discontinuous internal reflectors in the profiles collected over the thicker deposit of the western segment (Fig. 2E). These reflectors dip westward and, in places, downlap on an underlying unconformity. The difference in acoustic signatures of these shoreface deposits is likely an expression of the evolution of the barrier island. The eastern segment of the island has migrated landward via storm overwash, breaching, flood tidal delta formation, and subsequent marsh accretion on the back-barrier side for the past few centuries while the central segment of the island has been relatively stable over the past $~ 750-1000$ yrs (Leatherman, 1985; Leatherman and Allen, 1985; Lentz et al., 2013). The western segment of the island formed over the past 300-500 yrs as a westward prograding spit (Kumar and Saunders, 1974; Rampino and Sanders, 1981; Leatherman, 1985; Leatherman and Allen, 1985), with Fire Island Inlet classified as a barrier overlap inlet (Hayes, 1979; Hubbard et al., 1979). The unconformity at the base of the shoreface deposit in the western segment is thus interpreted as the Holocene transgressive surface that was subsequently buried via the seaward extent of the westward prograding spit. The westward dipping internal reflectors are interpreted to represent the spit elongation process. Alternatively, this unconformity could be interpreted as a tidal ravinement surface separating back-barrier estuarine deposits from overlying modern sediment. Lack of core data in this shoreface environment precludes a more definitive interpretation of the seismic-reflection profiles.

\subsection{Onshore sediment flux}

The morphology of the asymmetric sorted bedforms on the innercontinental shelf of the eastern segment of the study area (Figs. 1B and $8 \mathrm{~A}$ ), erosion of the southeastern flank of the Pleistocene headland offshore of central Fire Island (Fig. 7), and the migration of both sand waves (Fig. 8C) and sand ridges (Fig. 9) in the western segment, all indicate a general, net westerly transport direction for the modern sedimentary deposit. Schwab et al. (2013) identified this modern sediment deposit as a likely source required to balance the coastal sediment budget, suggesting that there exists an onshore component of this dominantly westward sediment flux (from the inner-continental shelf to the shoreface).

Although speculative, comparison of modern sediment thickness mapped from seismic-reflection data in 1996-1997 (Foster et al., 1999; Schwab et al., 2000a) and 2011 provides support to this hypothesis of onshore sediment flux. The comparison (Fig. 11), which is within the $\sim 50 \mathrm{~cm}$ vertical resolution limits of the subbottom systems used in the two surveys, supports the interpretation of a net westerly migration of the sand ridges, with erosion on the eastern flanks and crests of the ridges and deposition on the western flanks. A comparison of the total sediment volumes also suggests that the lower shoreface has accreted $7.8 \times 10^{6} \mathrm{~m}^{3}$ and the modern sand deposit on the inner-continental shelf was reduced by $3.1 \times 10^{6} \mathrm{~m}^{3}$ over the 15 -yr period. Depletion of the inner-continental shelf modern sand deposit during this time includes the mining of $2.4 \times 10^{6} \mathrm{~m}^{3}$ of sand for beach nourishment activities (Lentz et al., 2013). If the inner-continental shelf is a principal source of sand required to balance the coastal sediment budget (Schwab et al., 2013), this comparison suggests that the source includes erosion of the exposed Pleistocene glaciofluvial and early Holocene 


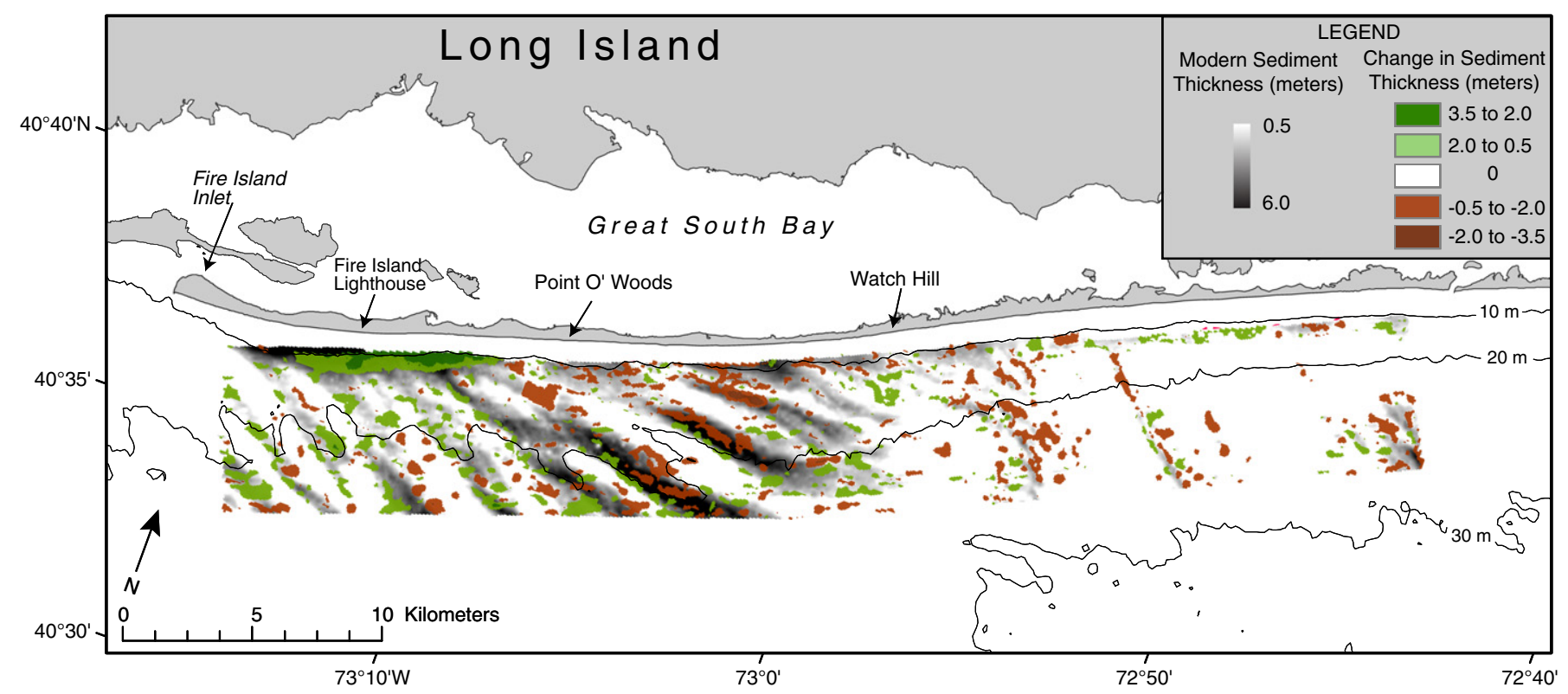

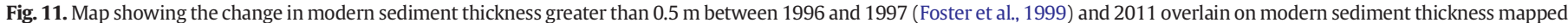
in 2011 (Fig. 4). Regional bathymetric contours are in meters.

channel-fill deposit in addition to the modern sediment. However, whether this comparison indicates that sediment is accumulating on the shoreface at the expense of long-term deflation of the innercontinental shelf due to the continuing modification of the ravinement surface or a more ephemeral oscillation cannot be determined by comparison of only two temporal data sets. Unfortunately, seismicreflection data penetration and resolution limitations do not allow a similar comparison to detect change in Pleistocene sediment thickness.

\section{Conclusions}

The present morphology of the Fire Island inner-continental shelf is a consequence of transgression of a Pleistocene glaciofluvial sedimentary deposit during the Holocene. The eroded remains of a Pleistocene outwash lobe compose a submerged headland offshore of central Fire Island. East of this headland, Pleistocene glaciofluvial and early Holocene channel-fill deposits are exposed over most of the inner-continental shelf and reworked into a series of sorted bedforms oriented $\sim 60^{\circ}-70^{\circ}$ to the shoreline. Backscatter patterns and asymmetry of the sorted bedforms suggest that reworked sediment is transported westward. Erosion of the southeast flank of the headland offshore of central Fire Island is thought to have yielded abundant fine- to medium-grained sand over the past $\sim 8000$ yrs leaving behind a coarse, erosional, gravelly lag deposit. It is suggested that this mobile sand was transported westward, forming the modern sediment deposit and subsequently modified by oceanographic processes into the field of shoreface-attached sand ridges that blanket the Holocene transgressive unconformity west of Watch Hill.

Erosion continues to shape the inner-continental shelf west of the Pleistocene headland where a relatively thick modern sand cover has formed. Erosion of the Pleistocene glaciofluvial and early Holocene channel-fill sedimentary deposits exposed in the troughs between the sand ridges has modified and continues to modify the Holocene transgressive unconformity, imparting a ridge-and-swale topography on the surface. Comparison of the sand ridge location to this underlying ravinement surface suggests that the seaward extent of the sand ridges has migrated at least $\sim 1000 \mathrm{~m}$ westward, although the rate of movement is unknown. This westward migration is further supported by the backscatter patterns associated with the sand ridges, with the higher backscatter, winnowed ridge flanks facing eastward, and by comparison of modern sediment thickness mapped in 1996-1997 and 2011. The southwest-facing flanks of the larger sand ridges in water depths $\leq 17 \mathrm{~m}$ terminate in $\sim 1$-m-high scarps. Where the sand ridges attach to the lower shoreface, these scarps define the seaward limit of the shoreface. It is suspected that these scarps are an expression of ongoing formation of the ravinement surface, where erosion in the troughs between the sand ridges results in modification of the seaward flanks of the sand ridges and the toe of the lower shoreface.

Comparison of the inner-continental shelf morphology east and west of the submerged Pleistocene headland may have broader application to understanding the role of available mobile sediment in determining the nature of inner-continental shelf morphology and adjacent barrier island evolution. In the area of relatively limited mobile modern sediment on the eastern inner-shelf segment of the study area, the shelf morphology is characterized by sorted bedforms and the barrier island is migrating landward at a relatively rapid rate. As the availability of mobile sediment increases west of Watch Hill, shoreface attached sand ridges characterize shelf morphology and the adjacent barrier island is relatively stable or accreting and growing via spit progradation at Democrat Point.

Comparison of modern sediment thickness mapped in 1996-1997 and in 2011 allows speculation that the lower shoreface sedimentary deposit has gained volume at the expense of deflation of the larger shoreface-attached ridges and the inner shelf in general. Although the processes responsible for this onshore-directed component of sediment flux remain unknown, analysis of observational data collected in 2012 using moored instruments and numerical modeling is being used to develop a better understanding of how shelf sediment responds to storm events and will be the subject of future publications.

\section{Acknowledgments}

We thank the captain and crew of the M.V. Scarlett Isabella for their skill and cooperation at sea. Emile Bergerone, Eric Moore, Charles Worley, and Barry Irwin, all with the USGS, and Brian Johnson from Coastal Carolina University provided technical support at sea. The authors appreciate helpful reviews of the manuscript by Deborah Hutchinson, Robert Thieler, Erika Lentz, and two anonymous reviewers. 
This research was funded by the U.S. Geological Survey, Coastal and Marine Geology Program. Any use of trade names or company names does not imply endorsement by the U.S. Geological Survey or Coastal Carolina University.

\section{References}

Belknap, D.F., Kraft, J.C., 1981. Preservation potential of transgressive coastal lithosomes on the U.S. Atlantic shelf. Marine Geology 42, 429-442.

Belknap, D.F., Kraft, J.C., 1985. Influence of antecedent geology on stratigraphic preservation potential and evolution of Delaware's barrier systems. Marine Geology 63, 235-262.

Cacchione, D.A., Drake, D.E., 1982. Measurements of storm-generated bottom stresses on the continental shelf. Journal of Geophysical Research 87, 1952-1960.

Cacchione, D.A., Drake, D.E., Grant, W.D., Tate, G.B., 1984. Rippled scour depressions on the inner-continental shelf of central California. Journal of Sedimentary Petrology $54,1280-1291$

Cacchione, D.A., Field, M.E., Drake, D.E., Tate, G.B., 1987. Cresentic dunes on the innercontinental shelf off northern California. Geology 15, 1134-1137.

Calvette, D., Falques, A., de Swart, H.E., Walgreen, M., 2001. Modelling the formation of shoreface-connected sand ridges on storm-dominated inner shelves. Journal of Fluid Mechanics 441, 169-193.

Cowell, P.J., Stive, M.J.F., Niedoroda, A.W., de Vriend, H.J., Swift, D.J.P., Kaminsky, G.M., Capobianco, M., 2003. The coastal-tract (part 1): a conceptual approach to aggregated modeling of low-order coastal change. Journal of Coastal Research 19, 812-827.

Demarest, J.M., Kraft, J.C., 1987. Stratigraphic record of Quaternary sea levels: implications for more ancient strata. In: Nummedal, D., Pilkey, O.H., Howard, J.D. (Eds.), Sea-level fluctuation and coastal evolution. SEPM Special Publication, 41, pp. 223-229.

Denny, J.F., Schwab, W.C., Baldwin, W.E., Barnhardt, W.A., Gayes, P.T., Morton, R.A., Warner, J.C., Driscoll, N.W., Voulgaris, G., 2013. Holocene sediment distribution on the inner continental shelf of northeastern South Carolina: implications for the regional sediment budget and long-term shoreline response. Continental Shelf Research 56, 56-70.

Dillon, W.P., Oldale, R.N., 1978. Late Quaternary sea-level curve: reinterpretation based on glaciotectonic influence. Geology 6, 56-60.

Duane, D.B., Field, M.E. Meisburger, E.P., Swift, D.J.P. Williams, S.J. 1972. Linear shoals on the Atlantic inner shelf, Florida to Long Island. In: Swift, D.J.P., Duane, D.B., Pilkey, O.H (Eds.), Shelf Sediment Transport. Dowden, Hutchinson, and Ross, pp. 447-449.

Emery, K.O., Uchupi, E., 1965. Structure of Georges Bank. Marine Geology 6, 56-60.

Emery, K.O., Uchupi, E., 1972. Western North Atlantic Ocean: topography, rocks, structure, water, life, sediment. American Association of Petroleum Geologists Memoir 17.

Engelhart, S.E., Peltier, W.R., Horton, B.P., 2011. Holocene relative sea-level changes and glacial isostatic adjustment of the U.S. Atlantic coast. Geology 39, 751-754.

Fagherazzi, S., Overeem, I., 2007. Models of deltaic and inner-continental shelf landform evolution. Annual Review of Earth and Planetary Sciences 35, 685-715.

Figueiredo, A.G., Swift, D.J.P., Stubblefield, W.L., Clarke, T.L., 1981. Sand ridges on the inner Atlantic shelf of North America: morphometric comparisons with Huthnance stability model. Geo-Marine Letters 1, 187-191.

Foster, D.S., Swift, B.A., Schwab, W.C., 1999. Stratigraphic framework maps of the nearshore area of southern Long Island from Fire Island to Montauk Point. New York. U.S. Geological Survey Open-file Report, pp. 99-559 (http://pubs.usgs.gov/of/1999/of99$559 /)$.

Gadd, P.E., Lavelle, J.W., Swift, D.J.P., 1978. Estimates of sand transport on the New York shelf using near-bottom current meter observations. Journal of Sedimentary Petrology 48, 239-252.

Gayes, P.T., Schwab, W.C., Driscoll, N.W., Morton, R.A., Baldwin, W.E., Denny, J.F., Harris M.S., Wright, E.E., Katuna, M.P., 2003. Sediment dispersal pathways and conceptual sediment budget in Long Bay: a southeast U.S. sediment starved embayment Proceedings of Coastal Sediments '03, Clear Water Beach. American Society of Civil Engineers, Florida, pp. 1-14.

Goff, J.A., Duncan, C.S., 2012. Re-examination of sand ridges on the middle and outer New Jersey shelf based on combined analysis of multibeam bathymetry and backscatter, seafloor grab samples and chirp seismic data. In: Li, M.Z., Sherwood, C.R., Hill, P.R. (Eds.), Sediments, Morphology and Sedimentary Processes on Continental Shelves: Advances in Technologies, Research, and Applications. John Wiley and Sons, Ltd, Chichester, West Sussex, pp. 121-142.

Goff, J.A., Swift, D.J.P., Duncan, C.S., Mayer, L.A., Hughes-Clarke, J., 1999. High resolution swath sonar investigation of sand ridge, dune and ribbon morphology in the offshore environment of the New Jersey margin. Marine Geology 161, 309-339.

Goff, J.A., Mayer, L.A., Traykovski, P., Buynevich, I., Wilkens, R., Raymond, R., Glang, G. Evans, R.L., Olson, H., Jenkins, C., 2005. Detailed investigation of sorted bedforms, o "rippled scour depressions," within the Martha's Vineyard Coastal Observatory, Massachusetts. Continental Shelf Research 25, 461-484.

Gofseyeff, S., 1952. Case history of Fire Island Inlet. N.Y. Proceedings Third Conference of Coastal Engineering, Council on Wave Research, pp. 272-305.

Gravens, M.B., Rosati, J.D., Wise, R.A., 1999. Fire Island Inlet to Montauk Point Reformulation Study (FIMP): Historical and Existing Condition Coastal Processes Assessment: USACE Draft Report, CHL-99-xx (307 pp.).

Hapke, C.J., Lentz, E.E., Gayes, P.T., McCoy, C.A., Hehre, R., Schwab, W.C., Williams, S.J 2010. A review of sediment budget imbalances along Fire Island, New York: can nearshore change explain the deficit? Journal of Coastal Research 26 (3), 510-522.

Hapke, C.J., Schwab, W.C., Gayes, P.T., McCoy, C.A., Viso, R., Lentz, E.E., 2011. Inner shelf morphologic controls on the dynamics of the beach and bar system, Fire Island,
New York. In: Wang, P., Rosati, J.D., Roberts, T.M. (Eds.), Proceedings of the Coastal Sediments 2011. American Society of Civil Engineers, pp. 1034-1047.

Hayes, M.O., 1979. Barrier island morphology as a function of tidal and wave regime. In: Leatherman, S.P. (Ed.), Barrier Islands: From the Gulf of St. Lawrence to the Gulf of Mexico. New York, Academic, pp. 1-27.

Hayes, M.O., Nairn, R.B., 2004. Natural maintenance of sand ridges and linear shoals on the U.S. Gulf and Atlantic continental shelves and the potential impact of dredging. Journal of Coastal Research 20 (1), 138-148.

Henkart, P., 2011. SIOSEIS - The Introduction: Software Package Sponsored by the National Science Foundation and the Scripps Industrial Associates. (http://sioseis. ucsd.edu/sioseis.html).

Hubbard, D.K., Oertel, G., Nummedal, D., 1979. The role of waves and tidal currents in the development of tidal-inlet sedimentary structures and sand body geometry: examples from North Carolina, South Carolina and Georgia. Journal of Sedimentary Research 49 (4), 1073-1091.

Hutchinson, D.R., Grow, J.A., 1984. New York Bight fault. Geological Society of America Bulletin 96, 975-989.

Huthnance, J.M., 1982. On one mechanism forming linear sand banks. Estuarine \& Coastal Marine Science 14, 277-299.

Kana, T.W., 1995. A mesoscale sediment budget for Long Island, New York. Marine Geology 126, 87-110.

Kraft, J.C., Chrzastawski, M.J., Belknap, D.F., Toscano, M.A., Fletcher, C.H., 1987. The transgressive barrier-lagoon coast of Delaware: morphostratigraphy, sedimentary sequences and responses to relative rise in sea level. In: Nummedal, D., Pilkey, O.H., Howard, J.D. (Eds.), Sea-level fluctuations and coastal evolution. SEPM Special Publication, 41, pp. 129-143.

Kumar, N., Saunders, J.E., 1974. Inlet sequence: a vertical succession of sedimentary structures and textures created by the lateral migration of tidal inlets. Sedimentology 21, 491-532.

Lavelle, J.W., Young, R.A., Swift, D.J.P., Clarke, T.L., 1978. Near-bottom sediment concentration and fluid velocity measurements on the inner-continental shelf. Journal of Geophysical Research 83, 6052-6062.

Leatherman, S.P., 1985. Geomorphic and stratigraphic analyses of Fire Island, New York. Marine Geology 63, 173-195.

Leatherman, S.P., Allen, J.R., 1985. Geomorphic analysis of the south shore barriers of Long Island, New York. Boston, Massachusetts, National Park Service, Technical Report (350 pp.).

Lentz, E.E., Hapke, C.J., Stockdon, H.F., Hehre, R.E., 2013. Improving understanding of nearterm barrier island evolution through multi-decadal assessment of morphologic change. Marine Geology 337, 125-139.

Lisiecki, L.E., Raymo, M.E., 2005. A Pliocene-Pleistocene stack of 57 globally distributed benthic $\delta^{18} \mathrm{O}$ records. Paleoceanography 20, PA1003. http://dx.doi.org/10.1029/ 2004PA001071.

McKinney, T.F., Stubblefield, W.L., Swift, D.J.P., 1974. Large-scale current lineations on the central New Jersey shelf: investigations by side-scan sonar. Marine Geology 17 (2), 79-102.

Miselis, J.L., McNinch, J.E., 2006. Calculating shoreline erosion potential using nearshore stratigraphy and sediment volume: Outer Banks, North Carolina. Journal of Geophysical Research 111, 1-15.

Morang, A., Rahoy, D.S., Grosskopf, W.G., 1999. Regional geologic characteristics along the south shore of Long Island, New York. Proceedings Coastal Sediments '99. American Society of Civil Engineers, pp. 1568-1583.

Murray, A.B., Thieler, E.R., 2004. A new hypothesis for the formation of large-scale innershelf sediment sorting and 'rippled scour depressions'. Continental Shelf Research 24, 295-315.

Nummedal, D., Swift, D.J.P., 1987. Transgressive stratigraphy at sequence-bounding unconformities: some principles derived from Holocene and Cretaceous examples. In: Nummedal, D., Pilkey, O.H., Howard, J.D. (Eds.), Sea Level Fluctuation and Coastal Evolution. SEPM, Tulsa, pp. 241-260.

Panuzio, F.L., 1968. The Atlantic coast of Long Island. Proceedings, 11th Coastal Eng. Conference. American Society of Civil Engineers, pp. 1222-1241.

Pilkey, O.H., Field, M.E., 1972. Onshore transportation of continental shelf sediment, Atlantic southeastern United States. Shelf Sediment Transport: Processes and Pattern. Dowden, Hutchinson, and Ross, Stroudsburg, PA, pp. 429-446.

Poag, C.W., 1978. Stratigraphy of the Atlantic continental shelf and slope of the United States. Annual Review of Earth and Planetary Sciences 6, 251-280.

Posamentier, H.W., 2002. Ancient shelf ridges - a potentially significant component of the transgressive system tract: case study from offshore northwest Java. AAPG Bulletin 86, 75-106.

Rampino, M.R., Sanders, J.E., 1981. Evolution of the barrier islands of southern Long Island, New York. Sedimentology 28, 37-47.

Riggs, S.R., Cleary, W.J., Snyder, S.W., 1995. Influence of inherited geologic framework on barrier shoreface morphology and dynamics. Marine Geology 126, 213-234.

Rosati, J.D., Gravens, M.B., Smith, W.G., 1999. Regional sediment budget for Fire Island to Montauk Point, New York. Proceedings of Coastal Sediments '99. American Society of Civil Engineers, pp. 802-817.

Saville, T., 1960. Sand transfer, beach control, and inlet improvements, Fire Island Inlet to Jones Beach, New York. In: Johnson, J.W. (Ed.), Proceedings 7th conference on coastal engineering. American Society of Civil Engineers, 2, pp. 785-807.

Schubert, C.E., 2009. Analysis of the shallow groundwater flow system at Fire Island National Seashore. U.S. Geological Survey Scientific Investigations Report, pp. 2009-5259 (106 pp.).

Schwab, W.C., Allison, M.A., Corso, W., Lotto, L.L., Butman, B., Buchholtz ten Brink, M., Denny, J.F., Danforth, W.W., Foster, D.S., 1997. Initial results of high-resolution seafloor mapping offshore of the New York-New Jersey metropolitan area using sidescan-sonar. Northeastern Geology and Environmental Sciences 19, 243-262. 
Schwab, W.C., Thieler, E.R., Allen, J.R., Foster, D.S., Swift, B.A., Denny, J.F., 2000a. Influence of inner-continental shelf geologic framework on the evolution and behavior of the barrier-island system between Fire Island Inlet and Shinnecock Inlet, Long Island, New York. Journal of Coastal Research 16, 408-422.

Schwab, W.C., Thieler, E.R., Denny, J.F., Danforth, W.W., Hill, J.C., 2000b. Seafloor sediment distribution off southern Long Island, New York. U.S. Geological Survey Open-file Report 00-243 (http://pubs.usgs.gov/of/2000/of00-243/default.htm).

Schwab, W.C., Baldwin, W.E., Hapke, C.J., Lentz, E.E., Gayes, P.T., Denny, J.F., List, J.H. Warner, J.C., 2013. Geologic evidence for onshore sediment transport from the inner-continental shelf: Fire Island, New York. Journal of Coastal Research 29 (3), 536-544.

Smith, W.G., Watson, K., Rahoy, D., Rasmussen, C., Headland, J.R., 1999. Historic geomorphology and dynamics of Fire Island, Moriches and Shinnecock Inlets, New York. Proceedings of Coastal Sediments '99. American Society of Civil Engineers, pp. 1597-1612.

Smolensky, D.A., Buston, H.T., Shernoff, P.K., 1989. Hydrologic framework of Long Island, New York. U.S. Geological Survey Hydrologic Investigations Atlas HA-709, scale: 1: 250,000, 3 sheets.

Snedden, J.W., Kreisa, R.P., Tillman, R.K., Culver, S.J., Schweller, W.J., 1999. An expanded model for modern shelf sand ridge genesis and evolution on the New Jersey Atlantic shelf. In: Bergman, K.M., Snedden, J.W. (Eds.), Isolated shallow marine sand bodies: sequence stratigraphic analysis and sedimentologic interpretation. Tulsa, Oklahoma: SEPM Special Publication, 64, pp. 147-164.

Son, C.S., Flemming, B.W., Bartholoma, A., Chang, T.S., 2012a. Long-term changes of surface sediments and morphology in relation to energy variations on shorefaceconnected ridges off Spiekeroog Island, southern North Sea. Journal of Sedimentary Research 82, 385-399.

Son, C.S., Flemming, B.W., Chang, T.S., 2012b. Sedimentary facies of shoreface-connected sand ridges off the East Frisian barrier-island coast, southern North Sea: climate controls and preservation potential. In: Li, M.Z., Sherwood, C.R., Hill, P.R. (Eds.) Sediments, morphology and sedimentary processes on continental shelves: advances in technologies, research and applications. International Association of Sedimentologists, Special Publication, 44, pp. 143-158.

Soren, J., 1978. Subsurface geology and paleogeography of Queens County, Long Island, New York. U.S. Geological Survey Water Resources Investigations Report, p. 77-34 (17 p.).

Sternberg, R.W., Larsen, L.H., 1975. Threshold of sediment movement by open ocean waves: observation. Deep-Sea Research 22, 299-309.

Stone, B.D., Borns, H.W., 1986. Pleistocene glacial and interglacial stratigraphy of New England, Long Island and adjacent Georges Bank and Gulf of Maine. In: Sibraba, V., Bowen, D.Q., Richmond, G.M. (Eds.), Quaternary Glaciations in the Northern Hemisphere. Pergamon Press, Oxford, pp. 38-52.

Stubblefield, W.L., McGrail, D.W., Kersey, D.G., 1984. Recognition of transgressive and post-transgressive sand ridges on the New Jersey continental shelf. In: Tillman, R.W., Siemers, C.T. (Eds.), Siliciclastic shelf sediments. SEPM Special Publication, 34, pp. 1-23.

Suter, R., deLaguna, W., Perlmutter, N.M., 1949. Mapping of geologic formations and aquifers of Long Island, New York. State of New York Department of Conservation Water Power and Control Commission. Bulletin GW-18, 212.

Swift, D.J.P., 1968. Coastal erosion and transgressive stratigraphy. Journal of Geology 76, 444-456.

Swift, D.J.P., 1976. Continental shelf sedimentation. In: Stanley, D.J., Swift, D.J.P. (Eds.), Marine Sediment Transport and Environmental Management. John Wiley and Sons, New York, pp. 311-350.

Swift, D.J.P., Field, M.E., 1981. Evolution of a classic sand ridge field: Maryland sector North American inner shelf. Sedimentology 28, 461-482.
Swift, D.J.P., Freeland, G.L., 1978. Current lineations and sand waves on the inner shelf, Middle Atlantic Bight of North America. Journal of Sedimentary Petrology 48, 1257-1266.

Swift, D.J.P., Moslow, T.F., 1982. Holocene transgression in south-central Long Island, New York - discussion. Journal of Sedimentary Petrology 52, 1014-1019.

Swift, D.J.P., Parker, G., Lanfredi, N.W., Perillo, B., Figge, K., 1978. Shoreface-connected sand ridges on American and European shelves: a comparison. Estuarine \& Coastal Marine Sciences 7, 257-273.

Thieler, E.R., Brill, A.L., Cleary, W.J., Hobbs, C.H., Gammisch, R.A., 1995. Geology of Wrightsville Beach, North Carolina shoreface; implications for the concept of shoreface profile of equilibrium. Marine Geology 126, 271-287.

Thieler, E.R., Pilkey, O.H., Cleary, W.J., Schwab, W.C., 2001. Modern sedimentation on the shoreface and inner continental shelf at Wrightsville Beach, North Carolina, U.S.A. Journal of Sedimentary Research 71 (6), 958-970.

Thieler, E.R., Foster, D.S., Himmelstoss, E.A., 2013. Geologic framework of the northern North Carolina, USA inner-continental shelf and its influence on coastal evolution. Marine Geology 348, 113-130.

Trowbridge, J.H., 1995. A mechanism for the formation and maintenance of the shore oblique sand ridges on storm-dominated shelves. Journal of Geophysical Research 100 (C8), 16,071-16,086.

Twichell, D.C., Flocks, J.G., Pendleton, E.A., Baldwin, W.E., 2013. Geologic controls on regional and local erosion rates of three northern Gulf of Mexico barrier-island systems. Journal of Sedimentary Research Special Issue 63, 32-45.

Van de Meene, J., Van Rihn, L., 2000. The shoreface-connected ridges along the central Dutch coast - part 1: field observations. Continental Shelf Research 20, 2295-2323.

Vincent, C.E., Young, R.A., Swift, D.J.P., 1982. Sediment transport on the Long Island shoreface, North American Atlantic shelf: role of waves and currents in shoreface maintenance. Continental Shelf Research 2 (2/3), 163-181.

Vis-Star, N.C., de Swart, H.E. Calvete, D., 2007. Effect of wave-topography interactions on the formation of sand ridges on the shelf. Journal of Geophysical Research 112, C06012. http://dx.doi.org/10.1029/2006JC003844.

Warner, J.C., Armstrong, B., Sylvester, C.S., Voulgaris, G., Nelson, T., Schwab, W.C., Denny, J.F. 2012. Storm-induced inner-continental shelf circulation and sediment transport: Long Bay, South Carolina. Continental Shelf Research 42, 51-63.

Wiberg, P.L., Smith, J.D., 1983. A comparison of field data and theoretical models for wave-current interactions at the bed on the continental shelf. Continental Shelf Research 2, 147-162.

Williams, S.J., 1976. Geomorphology, shallow subbottom structure and sediments of the Atlantic inner-continental shelf off Long Island, New York. Technical Paper No. 76-2. U.S. Army Corps of Engineers, CERC, Fort Belvoir, Virginia (123 pp.).

Williams, S.J., Duane, D.B., 1974. Geomorphology and Sediments of the Inner New York Bight Continental Shelf. TM-45, U.S. Army Corps of Engineers, Coastal Engineering Research Center, Fort Belvoir, Virginia (74 pp.).

Williams, S.J., Meisburger, E.P., 1987. Sand sources for the transgressive barrier coast of Long Island, New York: evidence for landward transport of shelf sediments. Proceedings of Coastal Sediments '87. American Society of Civil Engineers, New Orleans, Louisiana, pp. 1517-1532.

Wright, L.D., 1995. Morphodynamics of Inner-continental Shelves. CRC Press, Boca Raton, Florida.

Wright, L.D., Boon, J.D. Green, M.O., List, J.H. 1986. Response of the mid-shoreface of the southern Mid-Atlantic Bight to a "Northeaster". Geo-Marine Letters 6, 153-160.

Wright, L.D., Boon, J.D., Kim, S.C., List, J.H., 1991. Modes of cross-shore sediment transport on the shoreface of the Middle Atlantic Bight. Marine Geology 96, 19-51.

Wright, L.D., Xu, J.P., Madsen, O.S., 1994. Across-shelf benthic transport on the inner shelf of the Middle Atlantic Bight during the "Halloween Storm" of 1991. Marine Geology 118, 61-77. 